\title{
Results of Ground-Water, Surface-Water, and Water-Chemistry Monitoring, Black Mesa Area, Northeastern Arizona-1994
}

By G.R. LITTIN and S.A. MONROE

U.S. GEOLOGICAL SURVEY

Water-Resources Investigations Report 95-4238

Prepared in cooperation with the ARIZONA DEPARTMENT OF WATER RESOURCES and the BUREAU OF INDIAN AFFAIRS

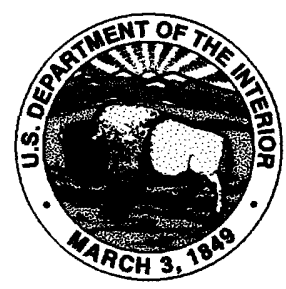




\section{CONTENTS}

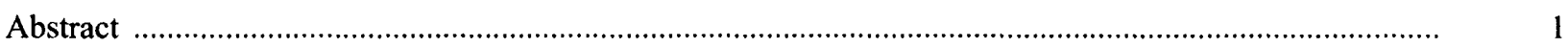

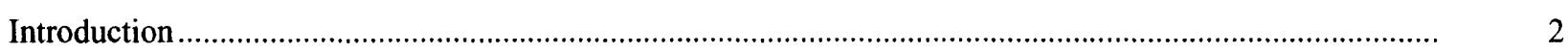

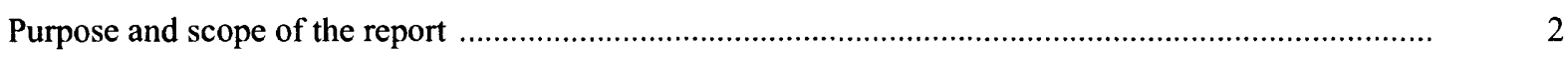

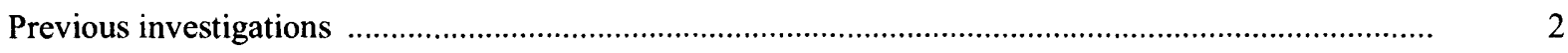

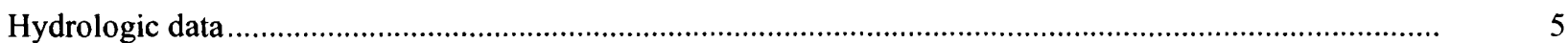

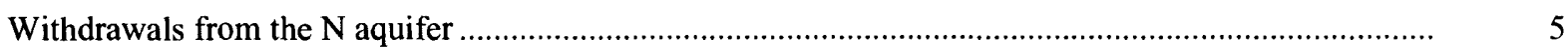

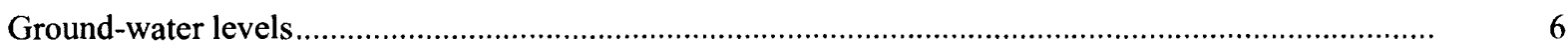

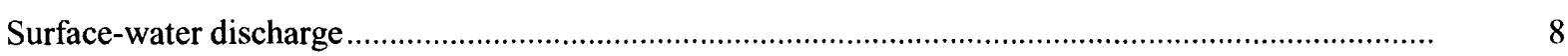

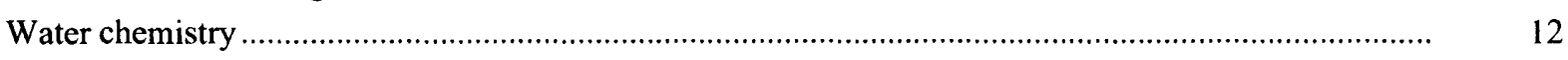

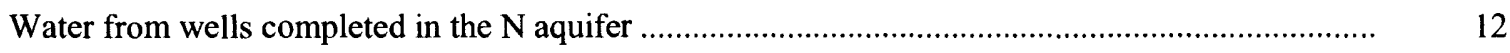

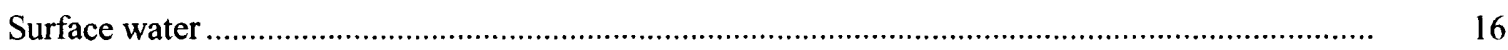

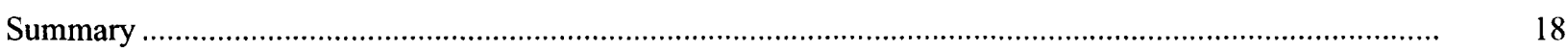

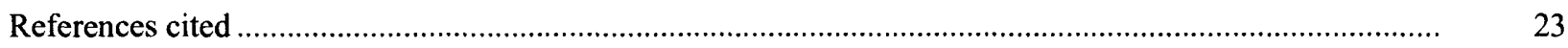

\section{FIGURES}

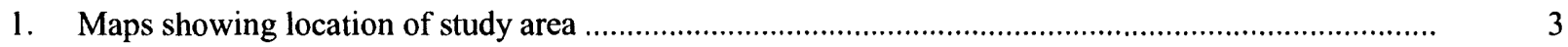

2. Diagram showing rock formations of the Black Mesa area................................................................

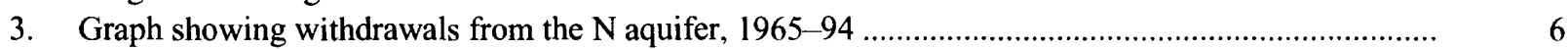

4. Map showing location of well systems monitored for withdrawals from the $\mathrm{N}$ aquifer, 1994

5. Map showing water-level changes in wells completed in the $\mathrm{N}$ aquifer from the start of data collection through 1994.

6. Hydrographs showing measured water-level changes in continuousrecord observation wells BM1 through BM6, 1963-94, and simulated water-level changes from Littin and Monroe, 1995

7. Map showing surface-water and water-chemistry data-collectio
8. Map showing water chemistry and distribution of dissolved solids in the $\mathrm{N}$ aquifer and Laguna Creek, 1994

9. Graphs showing dissolved-solids concentrations in water from wells, Keams Canyon Piñon PM6, Forest Lake NTUA1, and Kayenta PM2, 1982-94

\section{TABLES}

1. Withdrawals from the $\mathrm{N}$ aquifer, $1965-94$

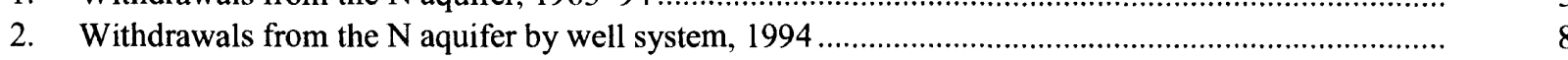

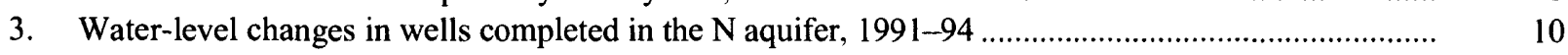

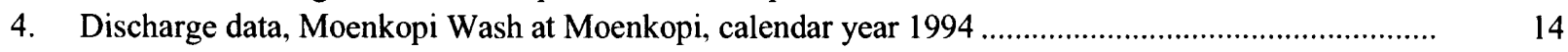

5. Discharge data from seepage investigation along Laguna Creek, 1994.

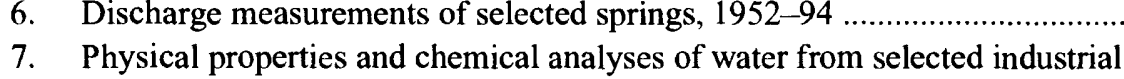
and municipal wells completed in the confined part of the $\mathrm{N}$ aquifer, 1994.

8. Specific conductance and concentrations of selected chemical constituents in water from industrial and municipal wells completed in the confined part of the $\mathrm{N}$ aquifer, 1980-94. 
9. Selected physical properties and chemical analyses of water from

Laguna Creek, November 1994.

10. Selected physical properties and chemical analyses of water from selected springs in the Black Mesa area, 1994

11. Specific conductance and concentrations of selected chemical constituents in water from springs that discharge from the $\mathrm{N}$ aquifer, 1952-94

\section{CONVERSION FACTORS}

\begin{tabular}{lll}
\hline \multicolumn{1}{c}{ Multiply } & \multicolumn{1}{c}{ By } & \multicolumn{1}{c}{ To obtain } \\
\hline foot $(\mathrm{ft})$ & 0.3048 & meter \\
mile $(\mathrm{mi})$ & 1.609 & kilometer \\
square $\mathrm{mile}\left(\mathrm{mi}^{2}\right)$ & 2.590 & square kilometer \\
acre-foot $(\mathrm{acre}-\mathrm{ft})$ & 0.001233 & cubic hectometer \\
cubic foot per second $\left(\mathrm{ft}^{3} / \mathrm{s}\right)$ & 0.02832 & cubic meter per second \\
gallon per minute $(\mathrm{gal} / \mathrm{min})$ & 0.06308 & liter per second \\
gallon per day $(\mathrm{gal} / \mathrm{d})$ & 0.003785 & cubic meter per day \\
\hline
\end{tabular}

Temperatures are given in degrees Celsius $\left({ }^{\circ} \mathrm{C}\right)$, which can be converted to degrees Fahrenheit $\left({ }^{\circ} \mathrm{F}\right)$ by the following equation:

$$
{ }^{\circ} \mathrm{F}=1.8\left({ }^{\circ} \mathrm{C}\right)+32
$$

\section{ABBREVIATED WATER-CHEMISTRY UNITS}

Chemical concentration is given only in metric units. Chemical concentration in water is given in milligrams per liter $(\mathrm{mg} / \mathrm{L})$ or micrograms per liter $(\mu \mathrm{g} / \mathrm{L})$. Milligrams per liter is a unit expressing the solute mass per unit volume (liter) of water. One thousand micrograms per liter is equivalent to 1 milligram per liter. For concentrations less than 7,000 milligrams per liter, the numerical value is about the same as for concentrations in parts per million. Specific conductance is given in microsiemens per centimeter $(\mu \mathrm{S} / \mathrm{cm})$ at $25^{\circ} \mathrm{C}$.

\section{VERTICAL DATUM}

Sea level: In this report, "sea level" refers to the National Geodetic Vertical Datum of 1929-A geodetic datum derived from a general adjustment of the first-order level nets of the United States and Canada formerly called "Sea Level Datum of 1929." 


\title{
Results of Ground-Water, Surface-Water, and Water-Chemistry Monitoring, Black Mesa Area, Northeastern Arizona—1994
}

\author{
By G.R. Littin and S.A. Monroe
}

\begin{abstract}
The Black Mesa monitoring program is designed to document long-term effects of ground-water pumping from the $\mathrm{N}$ aquifer by industrial and municipal users. The $\mathrm{N}$ aquifer is the major source of water in the 5,400-square-mile Black Mesa area, and the ground water occurs under confined and unconfined conditions. Monitoring activities include continuous and periodic measurements of (1) ground-water pumpage from the confined and unconfined areas of the aquifer, (2) ground-water levels in the confined and unconfined areas of the aquifer, (3) surface-water discharge, and (4) chemistry of the ground water and surface water.

In 1994, ground-water withdrawals for industrial and municipal use totaled about 7,000 acre-feet, which is an 8-percent increase from the previous year. Pumpage from the confined part of the aquifer increased by about 9 percent to 5,400 acre-feet, and pumpage from the unconfined part of the aquifer increased by about 2 percent to 1,600 acre-feet. Water-level declines in the confined area during 1994 were recorded in 10 of 16 wells, and the median change was a decline of about 2.3 feet as opposed to a decline of 3.3 feet for the previous year. The median change in water levels in the unconfined area was a rise of 0.1 foot in 1994 as opposed to a decline of 0.5 foot in 1993 .

Measured low-flow discharge along Moenkopi Wash decreased from 3.0 cubic feet per second in 1993 to 2.9 cubic feet per second in 1994. Eleven low-flow measurements were made along Laguna Creek between Tsegi, Arizona, and Chinle Wash to determine the amount of discharge that would occur as seepage from the $\mathrm{N}$ aquifer under optimal base-flow conditions. Discharge was 5.6 cubic feet per second near Tsegi and 1.5 cubic feet per second above the confluence with Chinle Wash. Maximum discharge was 5.9 cubic feet per second about 4 miles upstream from Dennehotso. Discharge was measured at three springs. The changes in discharge at Burro and Whisky Springs were small and within the uncertainty of measurement. Discharge at Moenkopi School Spring decreased from 14.6 gallons per minute in 1993 to 12.9 gallons per minute in 1994.

Regionally long-term water-chemistry data for wells and springs have shown no discernible change. A recent gradual increase in concentrations of dissolved solids, sulfate, and chloride in water from Forest Lake NTUA 1, however, indicates that, locally, water from the D aquifer may be mixing with water from the $\mathrm{N}$ aquifer.
\end{abstract}




\section{INTRODUCTION}

The $\mathrm{N}$ aquifer is the major source of water for industrial and municipal users in the 5,400-square-mile Black Mesa area (fig. 1), and the ground water occurs under confined and unconfined conditions. The aquifer consists of three rock formations-Navajo Sandstone, Kayenta Formation, and Lukachukai Member' ${ }^{1}$ of the Wingate Sandstone-which are all of early Jurassic age (Peterson, 1988). These formations are hydraulically connected and function as a single aquifer that is referred to as the $\mathrm{N}$ aquifer (fig. 2).

Total withdrawals for industrial and municipal use from the $\mathrm{N}$ aquifer in the Black Mesa area generally have increased during the last 26 years. Peabody Coal Company began operating a strip mine in the northern part of the mesa in 1968. The quantity of water pumped by the company increased from about 95 acre-ft in 1968 to a maximum of 4,740 acre-ft in 1982 . The quantity of water pumped in 1994 was 4,080 acre-ft. Withdrawals from the $\mathrm{N}$ aquifer for municipal use increased from an estimated 250 acre- $\mathrm{ft}$ in 1968 to a maximum of about 4,500 acre-ft in 1991 and decreased to about 2,940 acre-ft in 1994.

The Navajo Nation and Hopi Tribe have been concerned about the long-term effects of industrial withdrawals from the $\mathrm{N}$ aquifer on supplies for domestic and municipal purposes. These concerns led to an investigation of the water resources of the Black Mesa area in 1971 by the U.S. Geological Survey (USGS) in cooperation with the Arizona Department of Water Resources; in 1983, the Bureau of Indian Affairs joined the cooperative effort. Since 1983, the Navajo Tribal Utility Authority (NTUA); Peabody Coal Company; the Hopi Tribe; and the Western Navajo Agency, Chinle Agency, and Hopi Agency of the Bureau of Indian Affairs have assisted in the collection of ground-water data.

\footnotetext{
'The name Lukachukai Member was formally abandoned by Dubiel (1989) and is used herein for report continuity in the monitoring program as it relates to that part of the Wingate Sandstone included in the $\mathrm{N}$ aquifer.
}

\section{Purpose and Scope of the Report}

This report describes the results of ground-water, surface-water, and water-chemistry monitoring in the Black Mesa area from January to December 1994. The monitoring is designed to determine the effects of industrial and municipal pumpage from the $\mathrm{N}$ aquifer on water levels, stream and spring discharge, and water chemistry. Data-collection efforts include continuous and periodic measurements of ground water and surface water in the Black Mesa area. Ground-water data were collected from wells completed in the $\mathrm{N}$ aquifer and include data on pumpage, water levels, and chemistry. Surface-water data include discharge measurements at a continuous-record site, and discharge measurements and chemistry at sites along Laguna Creek and at selected springs.

\section{Previous Investigations}

Twelve progress reports have been prepared by the USGS on the monitoring phase of the program (USGS, 1978; G.W. Hill, hydrologist, USGS, written commun., 1982, 1983; Hill, 1985; Hill and Whetten, 1986; Hill and Sottilare, 1987; Hart and Sottilare, 1988, 1989; Sottilare, 1992; Littin, 1992, 1993; and Littin and Monroe, 1995). Most of the data obtained from the monitoring program are contained in these reports except for stream-discharge and sediment-discharge data from Moenkopi Wash collected before the 1986 water year; those data were published in USGS (1975-81), White and Garrett (1984-88), Wilson and Garrett (1988-89), Boner and others (1989-92), and Smith and others (1992-94). Eychaner (1983) described the results of mathematical-model simulations of the flow of ground water in the $\mathrm{N}$ aquifer. The model was used to predict the effects of withdrawals through the year 2014. The model was converted to a new model program and recalibrated by using revised estimates of selected aquifer characteristics and a finer spatial grid (Brown and Eychaner, 1988). Kister and Hatchett (1963) show selected chemical analyses of ground water from wells and springs throughout the Navajo and Hopi Indian Reservations. Cooley and others (1969) provide a detailed description of the regional hydrogeology. 


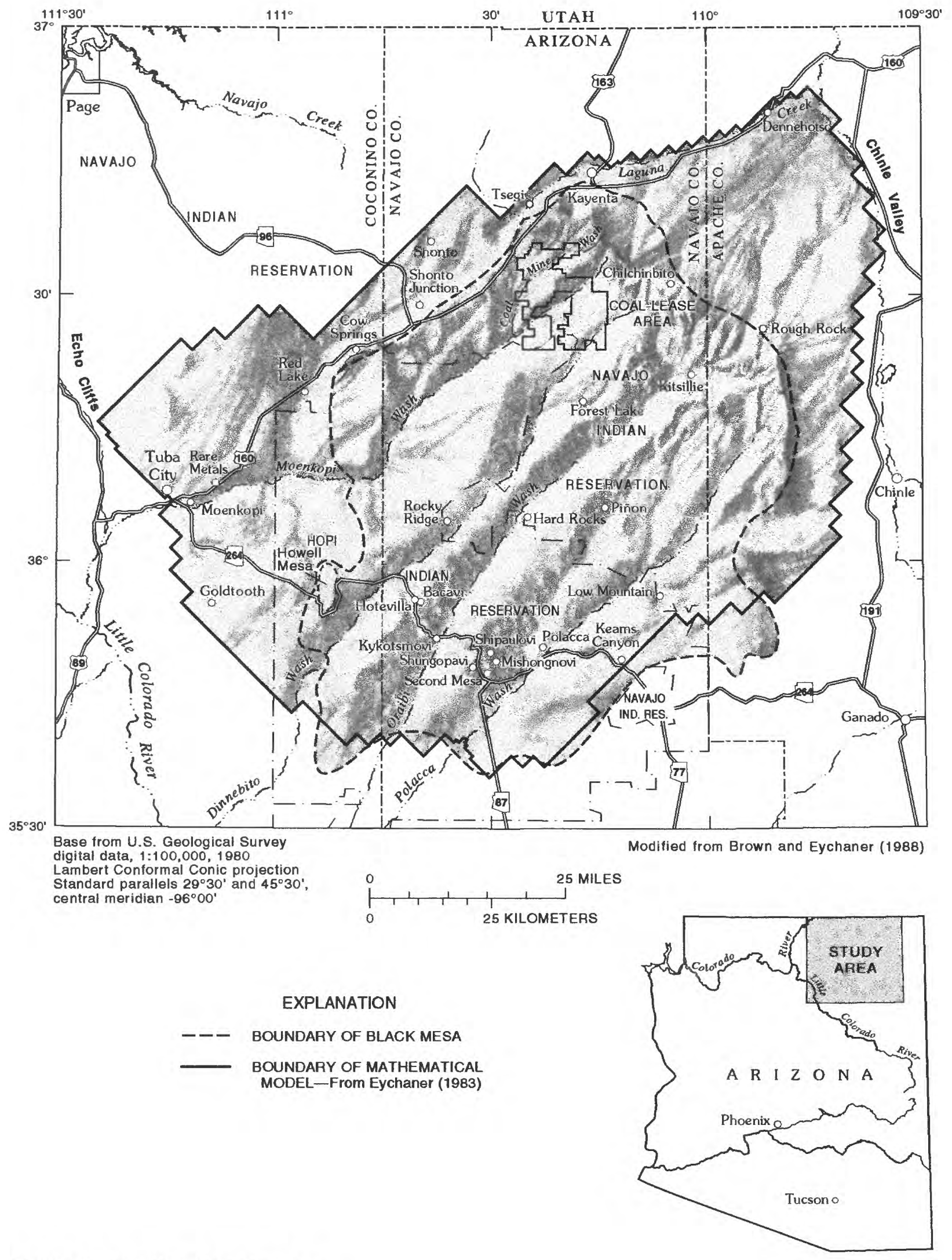

Figure 1. Location of study area. 


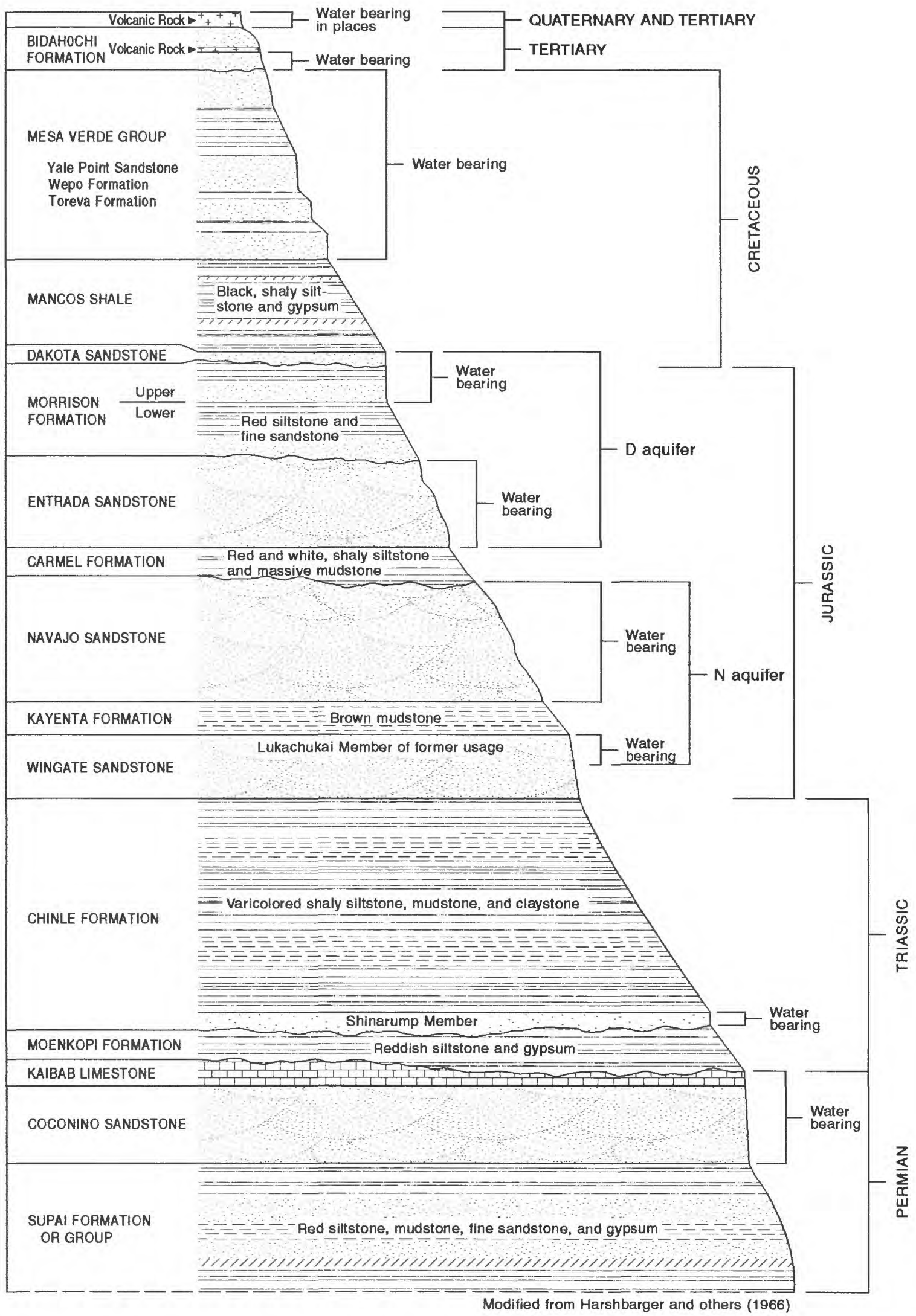

Figure 2. Rock formations of the Black Mesa area. The $N$ aquifer is approximately 1,000 feet thick. 


\section{HYDROLOGIC DATA}

Activities of the monitoring program in 1994 included metered and estimated ground-water withdrawals, measurements of ground-water levels, flow measurements of springs and surface water, and collection of water-chemistry samples to detect changes in the hydrologic conditions in the $\mathrm{N}$ aquifer. Ground-water withdrawals, continuousrecord water-level data from observation wells, and surface-water discharge data were collected from January through December 1994. Measurements of annual ground-water levels were made during November and December 1994. Chemical data are from ground-water samples collected during November and December 1994.

\section{Withdrawals from the $\mathbf{N}$ Aquifer}

Withdrawals from the $\mathrm{N}$ aquifer are separated into three categories-(1) industrial use from the confined area, (2) municipal use from the confined area, and (3) municipal use from the unconfined areas (table 1, fig. 3). The industrial category includes eight wells at the Peabody Coal Company well field in northern Black Mesa (fig. 4). The Bureau of Indian Affairs, Navajo Tribal Utility Authority, and the Hopi Tribe operate about 70 municipal wells that are in categories 2 and 3. Withdrawals from wells equipped with windmills are neither measured nor estimated.

Withdrawals from the $\mathrm{N}$ aquifer were compiled on the basis of metered and estimated data (tables 1 and 2). In some areas, only partial data were

Table 1. Withdrawals from the $\mathrm{N}$ aquifer, 1965-94

[Values are in acre-feet. Data for 1965-79 from Eychaner (1983)]

\begin{tabular}{|c|c|c|c|c|c|c|c|c|c|}
\hline \multirow[b]{2}{*}{ Year } & \multirow[b]{2}{*}{$\begin{array}{c}\text { Indus- } \\
\text { trial' }\end{array}$} & \multicolumn{2}{|c|}{ Municipal 2,3} & \multirow{2}{*}{$\begin{array}{l}\text { Total with- } \\
\text { drawals per } \\
\text { year }\end{array}$} & \multirow[b]{2}{*}{ Year } & \multirow[b]{2}{*}{$\begin{array}{l}\text { Indus- } \\
\text { trial }^{!}\end{array}$} & \multicolumn{2}{|c|}{ Municipal 2,3} & \multirow{2}{*}{$\begin{array}{c}\text { Total with- } \\
\text { drawals pe } \\
\text { year }\end{array}$} \\
\hline & & $\begin{array}{l}\text { Con- } \\
\text { fined }\end{array}$ & $\begin{array}{l}\text { Uncon- } \\
\text { fined }\end{array}$ & & & & $\begin{array}{l}\text { Con- } \\
\text { fined }\end{array}$ & $\begin{array}{l}\text { Uncon- } \\
\text { fined }\end{array}$ & \\
\hline 1965 & 0 & 50 & 20 & 70 & 1980 & 3,540 & 910 & 880 & 5,330 \\
\hline 1966 & 0 & 110 & 30 & 140 & 1981 & 4,010 & 960 & 1,000 & 5,970 \\
\hline 1967 & 0 & 120 & 50 & 170 & 1982 & 4,740 & 870 & 965 & 6,575 \\
\hline 1968 & 95 & 150 & 100 & 345 & 1983 & 4,460 & 1,360 & 1,280 & 7,100 \\
\hline 1969 & 43 & 200 & 100 & 343 & 1984 & 4,170 & 1,070 & 1,400 & 6,640 \\
\hline 1970 & 740 & 280 & 150 & 1,170 & 1985 & 2,520 & 1,040 & 1,160 & 4,720 \\
\hline 1971 & 1,900 & 340 & 150 & 2,390 & 1986 & 4,480 & 970 & 1,260 & 6,710 \\
\hline 1972 & 3,680 & 370 & 250 & 4,300 & 1987 & 3,830 & 1,130 & 1,280 & 6,240 \\
\hline 1973 & 3,520 & 530 & 300 & 4,350 & 1988 & 4,090 & 1,250 & 1,310 & 6,650 \\
\hline 1974 & 3,830 & 580 & 362 & 4,772 & 1989 & 3,450 & 1,070 & 1,400 & 5,920 \\
\hline 1975 & 3,500 & 600 & 508 & 4,608 & 1990 & 3,430 & 1,170 & 1,210 & 5,810 \\
\hline 1976 & 4,180 & 690 & 645 & 5,515 & 1991 & 4,020 & 1,140 & 3,360 & 8,520 \\
\hline 1977 & 4,090 & 750 & 726 & 5,566 & 1992 & 3,820 & 1,180 & 1,410 & 6,410 \\
\hline 1978 & 3,000 & 830 & 930 & 4,750 & 1993 & 3,700 & 1,250 & 1,570 & 6,520 \\
\hline 1979 & 3,500 & 860 & 930 & 5,290 & 1994 & 4,080 & 1,340 & 1,600 & 7,020 \\
\hline
\end{tabular}

\footnotetext{
${ }^{1}$ Metered pumpage by Peabody Coal Company at its mine on Black Mesa.

${ }^{2}$ Does not include withdrawals from the wells equipped with windmills.

${ }^{3}$ Includes estimated pumpage, 1965-73, and metered pumpage, 1974-79, at Tuba City; metered pumpage at Kayenta and estimated pumpage at Chilchinbito, Rough Rock, Piñon, Keams Canyon, and Kykotsmovi prior to 1980; metered and estimated pumpage furnished by the Navajo Tribal Utility Authority and the Bureau of Indian Affairs and collected by the U.S. Geological Survey, 1980-85; and metered pumpage furnished by the Navajo Tribal Utility Authority, the Bureau of Indian Affairs, various Hopi Village Administrations, and the U.S. Geological Survey, 198694 .
} 


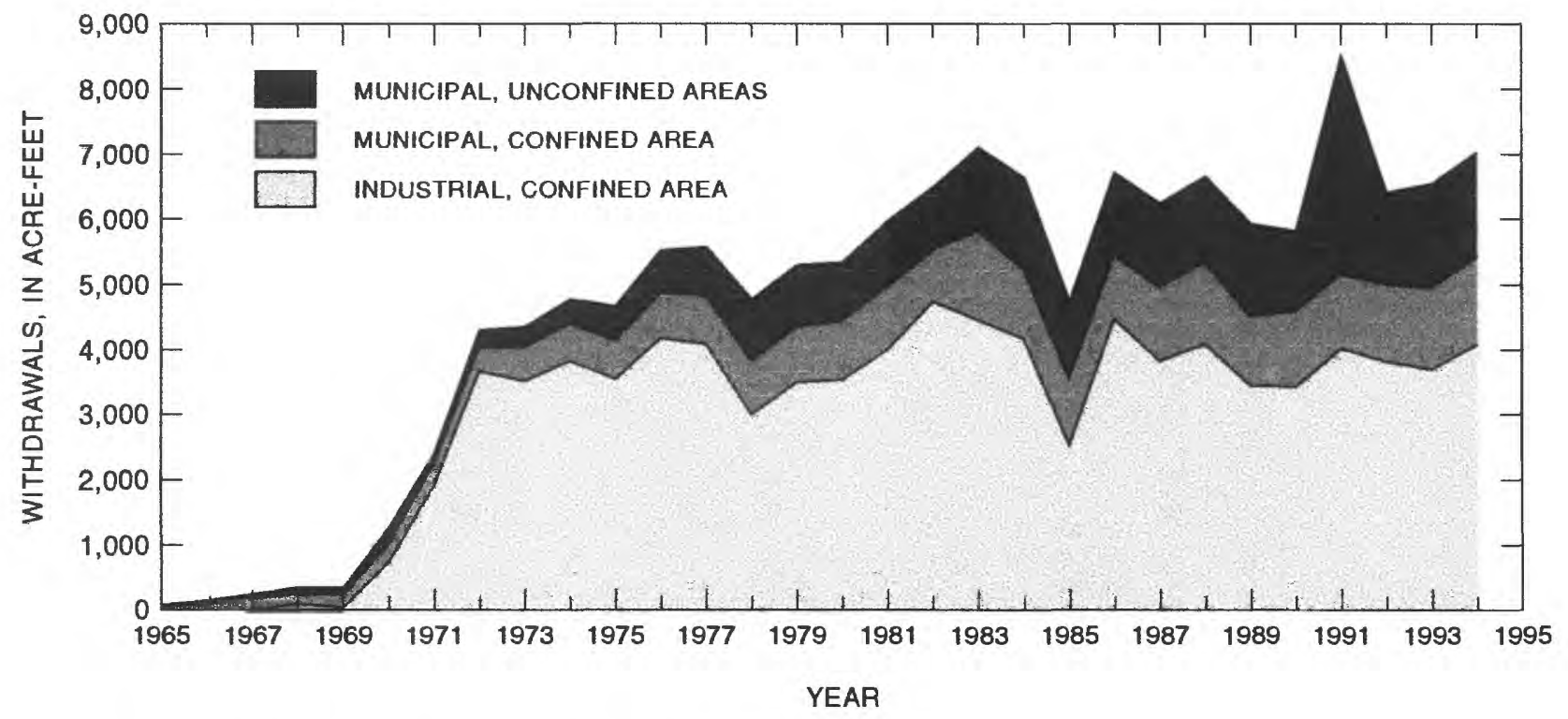

Figure 3. Withdrawals from the $\mathrm{N}$ aquifer, 1965-94.

available because of meter malfunctions, and pumpage was either prorated, on the basis of electrical usage, or computed on a per capita basis of $40 \mathrm{gal} / \mathrm{d}$. The per capita consumption is based on pumpage data and population figures (Arizona Department of Economic Security, 1991) for areas without commercial water use.

The total ground-water withdrawal in 1994 was about 7,000 acre-ft (table 1), which is an 8-percent increase in withdrawals compared with total withdrawals in 1993. Pumpage from the confined part of the aquifer increased by about 9 percent to 5,400 acre-ft, and pumpage from the unconfined part of the aquifer increased by about 2 percent to 1,600 acre-ft. Industrial pumpage accounted for about 4,100 acre- $\mathrm{ft}$ or about 58 percent of the total withdrawal, as compared to 57 percent in 1993. Municipal pumpage accounted for about 2,900 acre- $\mathrm{ft}$ and represents 42 percent of the total withdrawal as compared to 43 percent in 1993.

\section{Ground-Water Levels}

Ground water occurs under confined or artesian conditions in the central part of the study area and under unconfined or water-table conditions around the periphery (fig. 5). Annual ground-water levels were obtained from a network of 36 municipal and stock wells (table 3). Water-level changes from the earliest available data through 1994 ranged from a rise of $6.4 \mathrm{ft}$ at well $3 \mathrm{~K}-325$ near Tuba City to a decline of $156.8 \mathrm{ft}$ at Keams Canyon 2 well (fig. 5). In 1994, the maximum annual recorded rise in water level in the Black Mesa area was $18 \mathrm{ft}$ at the Kykotsmovi PM1 well. The maximum annual recorded water-level decline was $9.2 \mathrm{ft}$ at the Keams Canyon 2 well. Water-level declines in the confined area were measured in 10 of 16 wells and the median change was a decline of about $2.3 \mathrm{ft}$ as opposed to a decline of $3.3 \mathrm{ft}$ for the previous year. The median change in water levels in the unconfined area was a rise of $0.1 \mathrm{ft}$ in 1994 as opposed to a decline of $0.4 \mathrm{ft}$ in 1993.

Hydrographs of measured water levels in the six continuous-record observation wells (BM1 through BM6) are based on annual and continuous-record data beginning in about 1963 with well BM3 (fig. 6). Water-level data for wells BM1, BM2, BM4, and BM5 began in 1972; water-level data for well BM6 began in 1977.

Since 1972, water levels in wells completed in the unconfined area of the $\mathrm{N}$ aquifer have risen by 


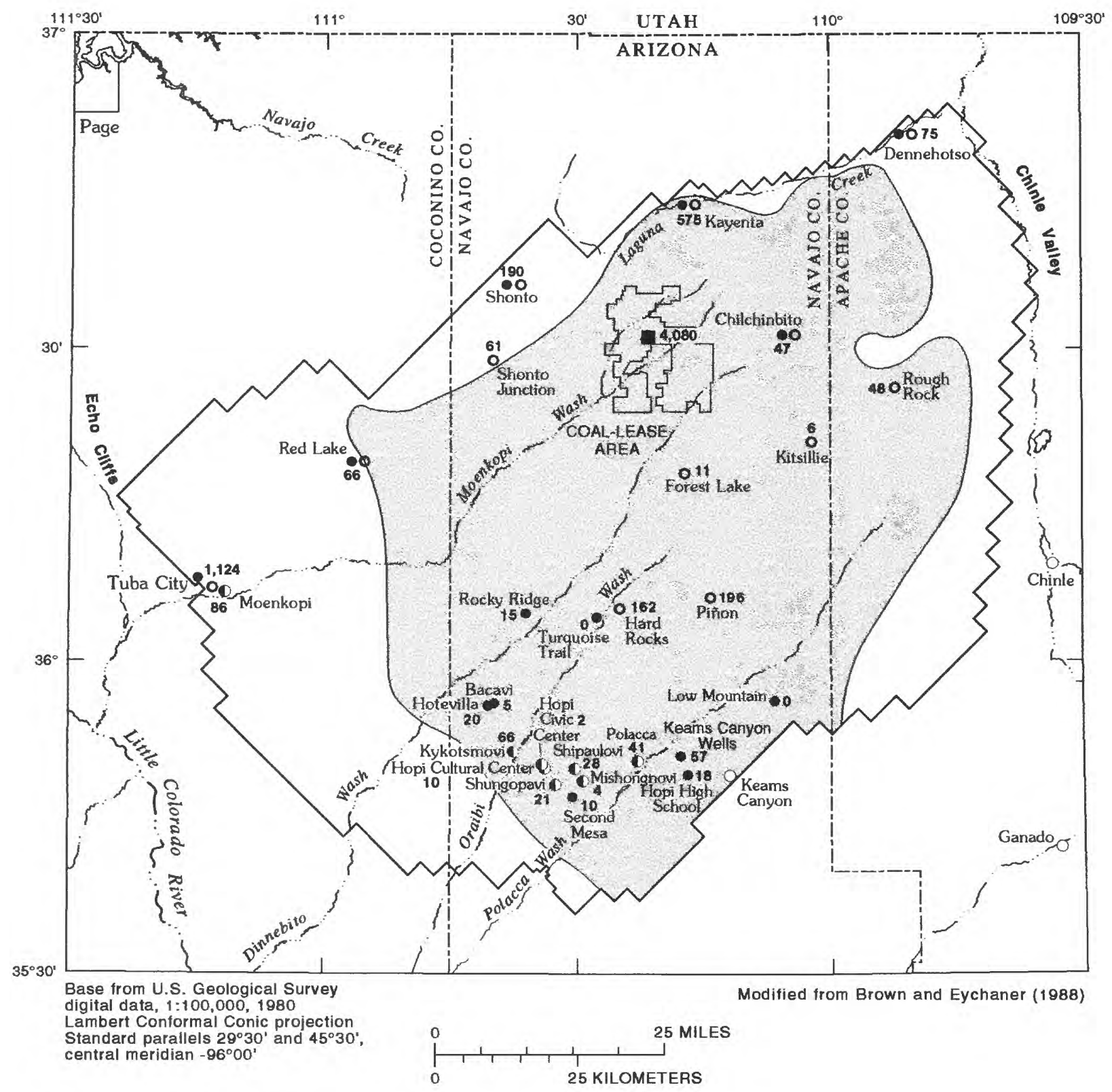

\section{EXPLANATION}
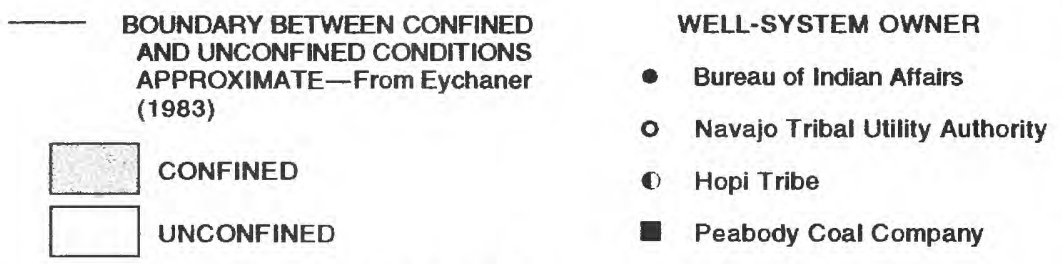

Hotevilla WITHDRAWALS FROM THE N AQUIFER - Hotevilla, is the village name; 20 , is the total withdrawal in acre-feet for 1994 location. The total is cumulative at locations served by multiple well owners UNCONFINED BOUNDARY OF MATHEMATICAL
MODEL-From Eychaner (1983)

Figure 4. Location of well systems monitored for withdrawals from the $\mathrm{N}$ aquifer, 1994. 
Table 2. Withdrawals from the $\mathrm{N}$ aquifer by well system, 1994

[Measurements, in acre-feet, are flowmeter data. BIA, Bureau of Indian Affairs; NTUA, Navajo Tribal Utility Authority; USGS, U.S. Geological Survey; Peabody, Peabody Coal Company; Hopi, Hopi Village Administrations. Contractor, Blaze Construction Company]

\begin{tabular}{|c|c|c|c|c|c|c|c|c|c|}
\hline Location & Owner & $\begin{array}{l}\text { Source } \\
\text { of data }\end{array}$ & $\begin{array}{c}\text { Confined } \\
\text { aquifer } \\
\text { well sys- } \\
\text { tems }\end{array}$ & $\begin{array}{l}\text { Uncon- } \\
\text { fined } \\
\text { aquifer } \\
\text { well sys- } \\
\text { tems }\end{array}$ & Location & Owner & $\begin{array}{l}\text { Source } \\
\text { of data }\end{array}$ & $\begin{array}{c}\text { Confined } \\
\text { aquifer } \\
\text { well sys- } \\
\text { tems }\end{array}$ & $\begin{array}{l}\text { Uncon- } \\
\text { fined } \\
\text { aquifer } \\
\text { well sys- } \\
\text { tems }\end{array}$ \\
\hline Chilchinbito & $\mathrm{BIA}$ & USGS/BIA & 7.0 & & Kayenta & NTUA & NTUA & 497.6 & \\
\hline Dennehotso & $\mathrm{B} 1 \mathrm{~A}$ & USGS/BIA & & 40.2 & Kitsillie & NTUA & NTUA & 5.5 & \\
\hline $\begin{array}{l}\text { Hopi High } \\
\text { School }\end{array}$ & $\mathrm{BIA}$ & USGS/BIA & 17.8 & & Pinon & NTUA & NTUA & 161.4 & \\
\hline Hotevilla & BIA & USGS/BIA & 19.8 & & Red Lake & NTUA & NTUA & & 48.4 \\
\hline Kayenta & BIA & USGS/BIA & 77.5 & & Rough Rock & NTUA & NTUA & 20.4 & \\
\hline Keams Canyon & $\mathrm{BIA}$ & USGS/BIA & 57.2 & & Shonto & NTUA & NTUA & & 14.4 \\
\hline Low Mountain & BIA & USGS/BIA & .2 & & $\begin{array}{l}\text { Shonto } \\
\text { Junction }\end{array}$ & NTUA & NTUA & & 61.0 \\
\hline Piñon & $\mathrm{BIA}$ & USGS/BIA & 34.1 & & Tuba City & NTUA & NTUA & & 992.0 \\
\hline Red Lake & $\mathrm{BIA}$ & USGS/BIA & & 17.8 & $\begin{array}{l}\text { Mine Well } \\
\text { Field }\end{array}$ & Peabody & Peabody & $4,078.8$ & \\
\hline Rocky Ridge & $\mathrm{BIA}$ & USGS/BIA & 14.6 & & Bacavi & Hopi & USGS/Hopi & 4.7 & \\
\hline Rough Rock & BIA & USGS/BIA & 27.2 & & $\begin{array}{l}\text { Hopi Civic } \\
\text { Center }\end{array}$ & Hopi & USGS/Hopi & 1.7 & \\
\hline Second Mesa & BIA & USGS/BIA & 9.6 & & $\begin{array}{l}\text { Hopi Cultural } \\
\text { Center }\end{array}$ & Hopi & USGS/Hopi & 10.0 & \\
\hline Shonto & $\mathrm{BIA}$ & USGS/BIA & & 175.1 & Kykotsmovi & Hopi & USGS/Hopi & 65.9 & \\
\hline Tuba City & BIA & USGS/BIA & & 131.5 & Mishongnovi & Hopi & USGS/Hopi & 4.4 & \\
\hline Turquoise Trail & $\mathrm{BIA}$ & Contractor & .1 & & Moenkopi & Hopi & USGS/Hopi & & ${ }^{1} 86.2$ \\
\hline Chilchinbito & NTUA & NTUA & 39.6 & & Polacca & Hopi & USGS/Hopi & 241 & \\
\hline Dennehotso & NTUA & NTUA & & 34.5 & Shipaulovi & Hopi & USGS/Hopi & 27.6 & \\
\hline Forest Lake & NTUA & NTUA & 10.6 & & Shungopovi & Hopi & USGS/Hopi & 20.8 & \\
\hline Hard Rocks & NTUA & NTUA & 161.7 & & & & & & \\
\hline
\end{tabular}

\footnotetext{
'Includes some estimated data because of meter malfunction during the calendar year on one or more wells in this municipal well system. Estimate based on electrical usage, the typical average daily pumpage prior to meter malfunction for the well in question, or on per capita use of 40 gallons per day. Does not include possible estimated data provided by cooperating agencies.

${ }^{2}$ Estimated. Well not metered.
}

$0.3 \mathrm{ft}$ in BMl and $1.1 \mathrm{ft}$ in BM4 (fig. 6). Water levels in wells completed in the confined area of the $\mathrm{N}$ aquifer have declined from about $58 \mathrm{ft}$ in well BM3 to $67.1 \mathrm{ft}$ in well BM5 since 1972. The water level of well BM6, which is completed in the confined area of the $\mathrm{N}$ aquifer, has declined $79.8 \mathrm{ft}$ since 1977. Records for the oldest well, BM3, indicate a water-level decline of $79 \mathrm{ft}$ since 1963 . A water-level decline of $23 \mathrm{ft}$ was recorded at well BM3 from 1963 to 1967 even though there was no significant pumpage.

\section{Surface-Water Discharge}

Outflow from the $\mathrm{N}$ aquifer is mainly surface flow in Moenkopi Wash and Laguna Creek ${ }^{2}$ and springs near the boundaries of the aquifer (Davis and others, 1963). Discharge data were collected at

\footnotetext{
${ }^{2}$ Measurements formerly made on Laguna Creek have been discontinued because variable amounts of snowmelt and sewage effluent often are included in the flow, and the data did not represent discharge solely from the $\mathrm{N}$ aquifer.
} 


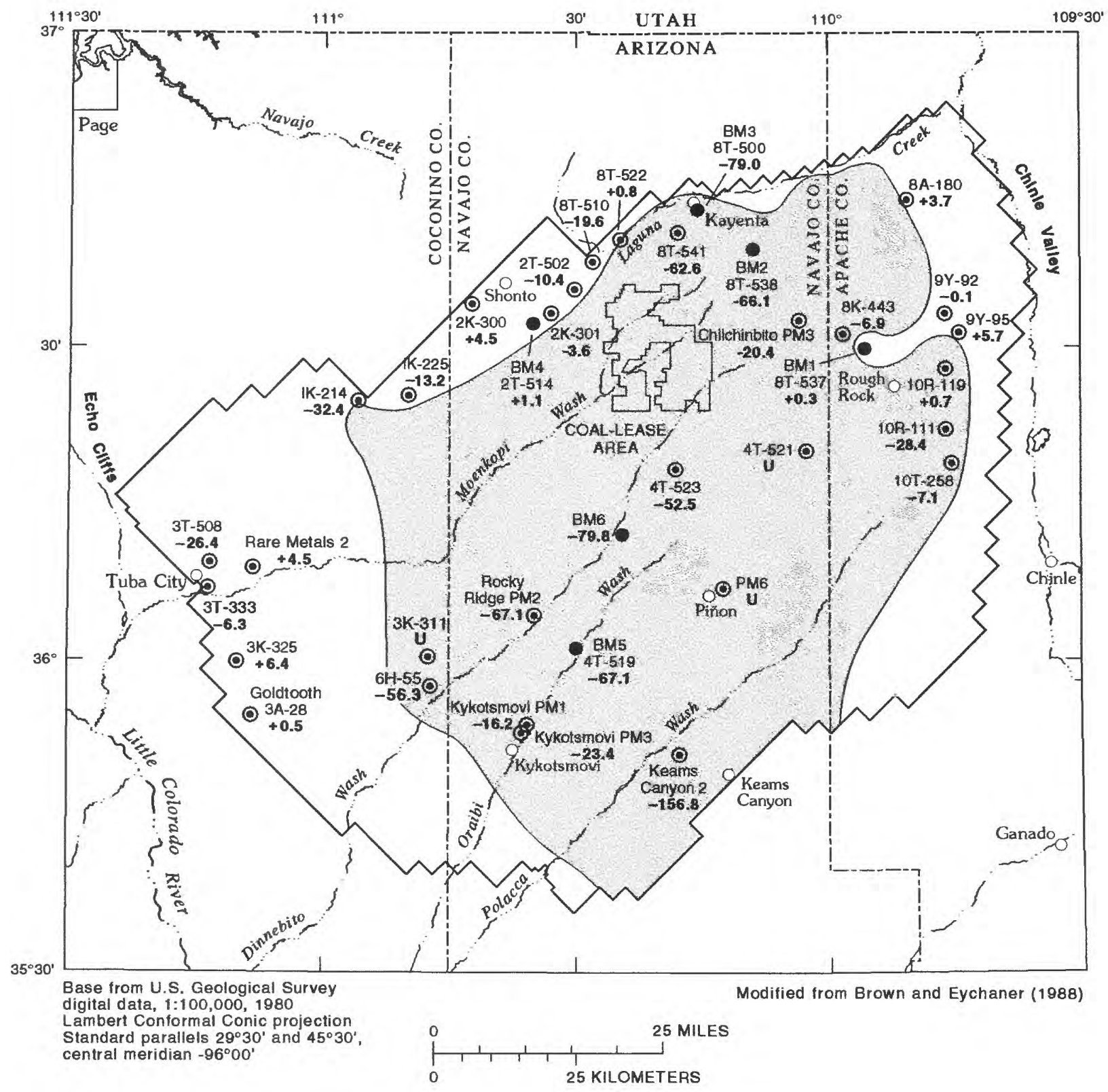

EXPLANATION

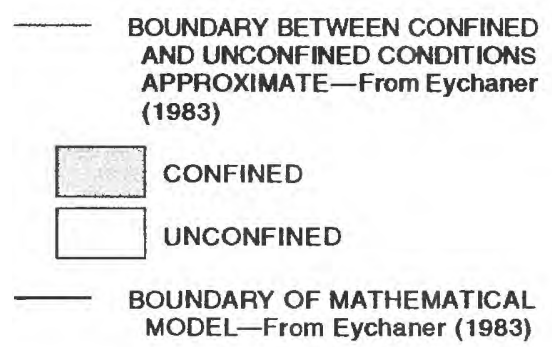

$\begin{array}{cl}\text { O } & \text { WELL IN WHICH DEPTH TO } \\ \text { 4T-523 } & \text { WATER WAS MEASURED } \\ -52.5 & \text { ANNUALLY - First entry, } \\ & \text { 4T-523, is Bureau of Indian } \\ & \text { Affairs site number; second } \\ \text { entry, }-52.5, \text { is change in } \\ \text { water level, in feet, between } \\ \text { measurements made during } \\ \text { the prestress period and } \\ \text { measurements made during } \\ \text { 1994. U, unable to measure }\end{array}$

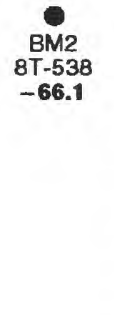

CONTINUOUS WATER-LEVEL RECORDING SITE (OBSERVATION WELL) MAINTAINED BY THE U.S. GEOLOGICAL SURVEY-First entry, BM2 is U.S. Geological Survey well number; second entry, 8T-538, is Bureau of Indian Affairs site number; third entry, -66.1, is change in water level, in feet, from 1972 to 1994

Figure 5. Water-level changes in wells completed in the $\mathrm{N}$ aquifer from the start of data collection through 1994. 
Table 3. Water-level changes in wells completed in the $\mathrm{N}$ aquifer, 1991-94

[Dashes indicate no data]

\begin{tabular}{|c|c|c|c|c|c|c|}
\hline \multirow{2}{*}{$\begin{array}{c}\text { Well system } \\
\text { or location } \\
\text { name }\end{array}$} & \multirow{2}{*}{$\begin{array}{c}\text { Bureau of Indian } \\
\text { Affairs site } \\
\text { number }\end{array}$} & \multicolumn{4}{|c|}{$\begin{array}{l}\text { Change in water level from preceding water year, } \\
\text { in feet }\end{array}$} & \multirow{2}{*}{$\begin{array}{l}\text { Water level, in } \\
\text { feet, below land } \\
\text { surface,1994 }\end{array}$} \\
\hline & & 1991 & 1992 & 1993 & 1994 & \\
\hline \multicolumn{7}{|c|}{ Unconfined } \\
\hline $\mathrm{BM} 1^{1} \ldots \ldots$ & $8 \mathrm{~T}-537$ & 0 & +0.4 & +0.2 & +0.1 & 373.7 \\
\hline BM4' & $2 \mathrm{~T}-514$ & 0 & -.2 & +.3 & +.1 & 215.9 \\
\hline 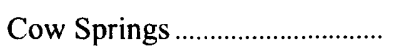 & $1 \mathrm{~K}-225$ & -.5 & +.9 & +.9 & +.3 & 46.8 \\
\hline Goldtooth & $3 A-28$ & -.1 & $\left({ }^{2}\right)$ & ${ }^{3}-3.0$ & +3.2 & 229.5 \\
\hline Long House Valley ......................... & $8 \mathrm{~T}-510$ & -.2 & +1.1 & -.6 & +.4 & 118.6 \\
\hline Marsh Pass & $8 \mathrm{~T}-522$ & -1.0 & +.1 & +.6 & -.6 & 124.7 \\
\hline Northeast Rough Rock ............. & $8 \mathrm{~A}-180$ & -.1 & 0 & 0 & +.1 & 43.2 \\
\hline 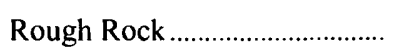 & $9 Y-95$ & -- & $3+1.7$ & -2.2 & -5.7 & 113.8 \\
\hline 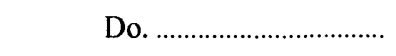 & $9 Y-92$ & -1.4 & +3.0 & -1.6 & -.5 & 168.9 \\
\hline 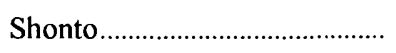 & $2 \mathrm{~K}-300$ & +.6 & -.1 & +.2 & -.3 & 172.0 \\
\hline 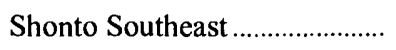 & $2 \mathrm{~K}-301$ & +.6 & -.6 & +.1 & -.7 & 287.5 \\
\hline Do. & $2 \mathrm{~T}-502$ & +.1 & +.7 & -1.1 & -1.5 & 416.2 \\
\hline 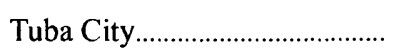 & $3 \mathrm{~T}-333$ & +.8 & +.7 & $\left({ }^{2}\right)$ & $3-.5$ & 29.3 \\
\hline Do. & $3 \mathrm{~K}-325$ & -.5 & +.9 & +.1 & +.3 & 201.6 \\
\hline Do. & Rare Metals 2 & +.8 & $\left({ }^{2}\right)$ & $\left({ }^{2}\right)$ & $3+3.3$ & 52.5 \\
\hline Tuba NTUA 1 & $3 \mathrm{~T}-508$ & +2.5 & +9.4 & -1.9 & -2.5 & 55.4 \\
\hline Tuba NTUA 4 ............................... & $3 \mathrm{~T}-546$ & +5.6 & +5.1 & -.7 & +1.8 & 56.1 \\
\hline 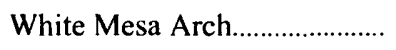 & $1 \mathrm{~K}-214$ & +.8 & +.1 & -.4 & +.5 & 220.4 \\
\hline \multicolumn{7}{|c|}{ Confined } \\
\hline BM2' & $8 \mathrm{~T}-538$ & -3.7 & -2.2 & -1.1 & -2.3 & 191.1 \\
\hline 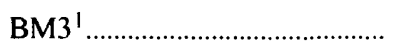 & $8 \mathrm{~T}-500$ & -.4 & -7.1 & -4.1 & +8.8 & 139.0 \\
\hline 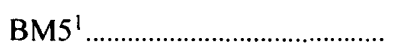 & $4 \mathrm{~T}-519$ & -4.0 & -1.3 & -3.9 & -4.9 & 390.9 \\
\hline BM6 $^{1}$ & BM6 & -4.0 & -3.4 & -4.2 & -3.2 & 815.4 \\
\hline Chilchinbito & PM3 & +1.5 & -2.8 & +3.2 & +1.2 & 425.4 \\
\hline Forest Lake NTUA I ................ & $4 \mathrm{~T}-523$ & -18.7 & +13.5 & -3.9 & -4.6 & $1,148.5$ \\
\hline 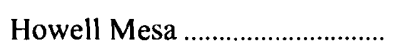 & $6 \mathrm{H}-55$ & -4.6 & +2.5 & +.5 & -.5 & 268.3 \\
\hline Kayenta West & $8 \mathrm{~T}-54 \mathrm{I}$ & +3.6 & $\left({ }^{2}\right)$ & ${ }^{3}-22.3$ & +4.9 & 289.6 \\
\hline 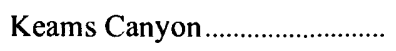 & 2 & +8.4 & -8.6 & $4-33.6$ & -9.2 & 449.3 \\
\hline 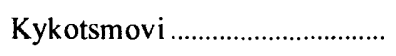 & PM1 & $3+1.5$ & -3.1 & +8.2 & +18.0 & 236.2 \\
\hline 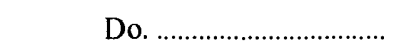 & PM3 & $\left({ }^{2}\right)$ & $\left({ }^{2}\right)$ & $\left({ }^{2}\right)$ & $3-7.2$ & 233.4 \\
\hline Piñon & PM6 & $(2)$ & $3-3.6$ & -11.6 & $\left({ }^{2}\right)$ & - \\
\hline Do. & $3 \mathrm{~K}-31 \mathrm{I}$ & $\left({ }^{2}\right)$ & $\left({ }^{2}\right)$ & $3-7.1$ & $\left({ }^{2}\right)$ & -- \\
\hline 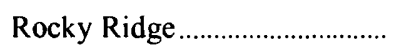 & PM2 & -5.4 & -.8 & -3.8 & -3.4 & 499.9 \\
\hline Rough Rock & 10R-119 & +.6 & -1.9 & +6.8 & -6.1 & 255.9 \\
\hline 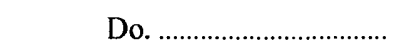 & $10 \mathrm{~T}-258$ & $\left({ }^{2}\right)$ & $3-3.0$ & +.6 & +4.1 & 308.1 \\
\hline 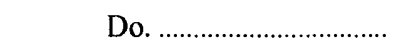 & $10 \mathrm{R}-111$ & +.2 & -3.7 & +3.0 & 0 & 198.4 \\
\hline Sweetwater Mesa ....................... & $8 \mathrm{~K}-443$ & $3-1.8$ & -.2 & -.8 & -.1 & 536.3 \\
\hline
\end{tabular}

\footnotetext{
${ }^{1}$ Continuous recorder.

${ }^{2}$ Unable to measure.

${ }^{3}$ Change in water level from last measurement 2 or more years earlier.

${ }^{4}$ Measurement may have been affected by obstructions in well and (or) nearby pumping.
} 


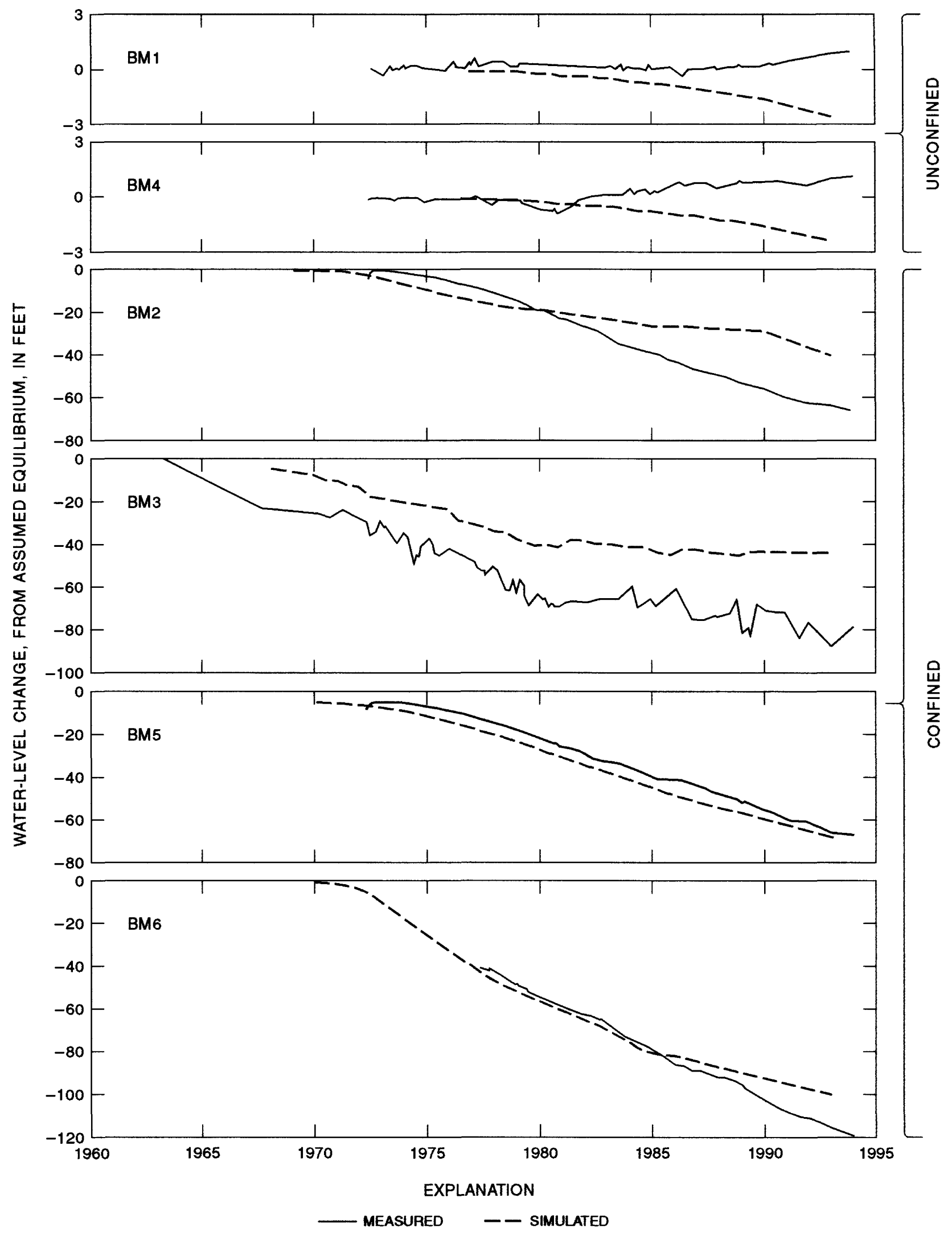

Figure 6. Measured water-level changes in continuous-record observation wells BM1 through BM6, 1963-94, and simulated water-level changes from Littin and Monroe, 1995. 
the continuous-record streamflow station, Moenkopi Wash at Moenkopi (09401260; fig. 7, table 4). Low flow in Moenkopi Wash historically is based on discharge measurements made during November through February. Discharge data collected during these months are considered representative of low flow because the effect of stream loss from evapotranspiration and gain from snowmelt and rainfall (which generally occurs during temperate months) is minimized.

A low-flow measurement of $2.9 \mathrm{ft}^{3} / \mathrm{s}$ was made at the Moenkopi gage in November 1994. The mean daily discharge for the same month was $2.6 \mathrm{ft}^{3} / \mathrm{s}$. Measurements made in December through February were affected by snowmelt and are not included. The mean daily discharge for those months, however, was $3.6 \mathrm{ft}^{3} / \mathrm{s}$. Mean daily discharges for previous water years have been published by the USGS (1963-81), White and Garrett (1984, 1986-88), Wilson and Garrett (1988-89), Boner and others (1989-92), Garrett and Gellenbeck (1991), and Smith and others, (1993-94). These data indicate that low flow in Moenkopi Wash during November through February has remained fairly constant at about $3 \mathrm{ft}^{3} / \mathrm{s}$ since the streamflow-gaging station was installed in 1976.

On November 16, 1994, 11 low-flow measurements were made as a part of a seepage investigation along a 40-mile reach of Laguna Creek between Tsegi and its confluence with Chinle Wash (fig. 7, table 5). The measurements were made to determine the amount of discharge that would occur (under optimal base-flow conditions) as seepage from the $\mathrm{N}$ aquifer. Measurements were made in November to reduce the chance of stream loss from evapotranspiration or gain from snowmelt. No measurable precipitation was reported in the weeks before the measurements were made. Air temperatures ranged from $8^{\circ} \mathrm{C}$ to $13^{\circ} \mathrm{C}$ throughout the day. Although discharge decreased from $5.6 \mathrm{ft}^{3} / \mathrm{s}$ at LSI-1 near Tsegi, Arizona, to $1.5 \mathrm{ft}^{3} / \mathrm{s}$ at LSI-11, above the confluence with Chinle Wash, the maximum discharge measured was $5.9 \mathrm{ft}^{3} / \mathrm{s}$ at LSI-8, about $4 \mathrm{mi}$ west of Dennehotso. The minimum discharge was $0.7 \mathrm{ft}^{3} / \mathrm{s}$ at LSI-3, which is below a diversion dam about $3 \mathrm{mi}$ west of Kayenta. Much of the variation in measured discharge along Laguna Creek probably was due to variations in underflow as a function of alluvial geometry. Other contributing sources included fringe ice and discharge from sewage lagoons at Kayenta and Dennehotso. The sewage discharge provided an additional $0.53 \mathrm{ft}^{3} / \mathrm{s}$ of flow to the stream at Kayenta during the investigation (Freddy Bosley, NTUA, oral commun., 1994). Discharge from the Dennehotso lagoon was estimated to be less than $0.1 \mathrm{ft}^{3} / \mathrm{s}$.

Burro, Moenkopi, and Whisky Springs were selected for discharge measurements as part of the monitoring program during 1994 (fig. 6, table 6). The discharge from Burro Spring was $0.25 \mathrm{gal} / \mathrm{min}$ as compared with $0.3 \mathrm{gal} / \mathrm{min}$ measured in 1993 . Because no discrete point of discharge could be located at Whisky Spring, discharge was estimated to be about $0.1 \mathrm{gal} / \mathrm{min}$ the same as in 1993 . Discharge from Moenkopi School Spring decreased by about $1.7 \mathrm{gal} / \mathrm{min}$ from the measurement of the previous year. The changes in discharge at Burro and Whisky Springs were small and within the uncertainty of measurement. At Moenkopi, the change in spring discharge probably is caused by the cumulative effect of local recharge in addition to the regional ground-water flow; however, discharge does not appear to be affected by changes in local or regional pumping from the previous year.

\section{Water Chemistry}

\section{Water from Wells Completed in the $\mathbf{N}$ Aquifer}

Water from the $\mathrm{N}$ aquifer is analyzed for selected chemical constituents to determine if declining hydraulic heads are inducing vertical leakage from overlying formations. The hydraulic head in the overlying D aquifer in 1964 averaged about $300 \mathrm{ft}$ higher than the hydraulic head in the $\mathrm{N}$ aquifer. This higher head may cause water to move downward through the confining beds from the D aquifer to the $\mathrm{N}$ aquifer (Eychaner, 1983). Differences in the concentration of dissolved constituents in the water from the $\mathrm{D}$ aquifer and the $\mathrm{N}$ aquifer, however, indicate that the quantity of downward leakage must be small. On the average, the concentration of dissolved solids in water from the $\mathrm{D}$ aquifer is about 7 times greater than that of water from the $\mathrm{N}$ aquifer, concentration of chloride ions is about 11 times greater, and the concentration of sulfate ions is about 30 times greater (Eychaner, 


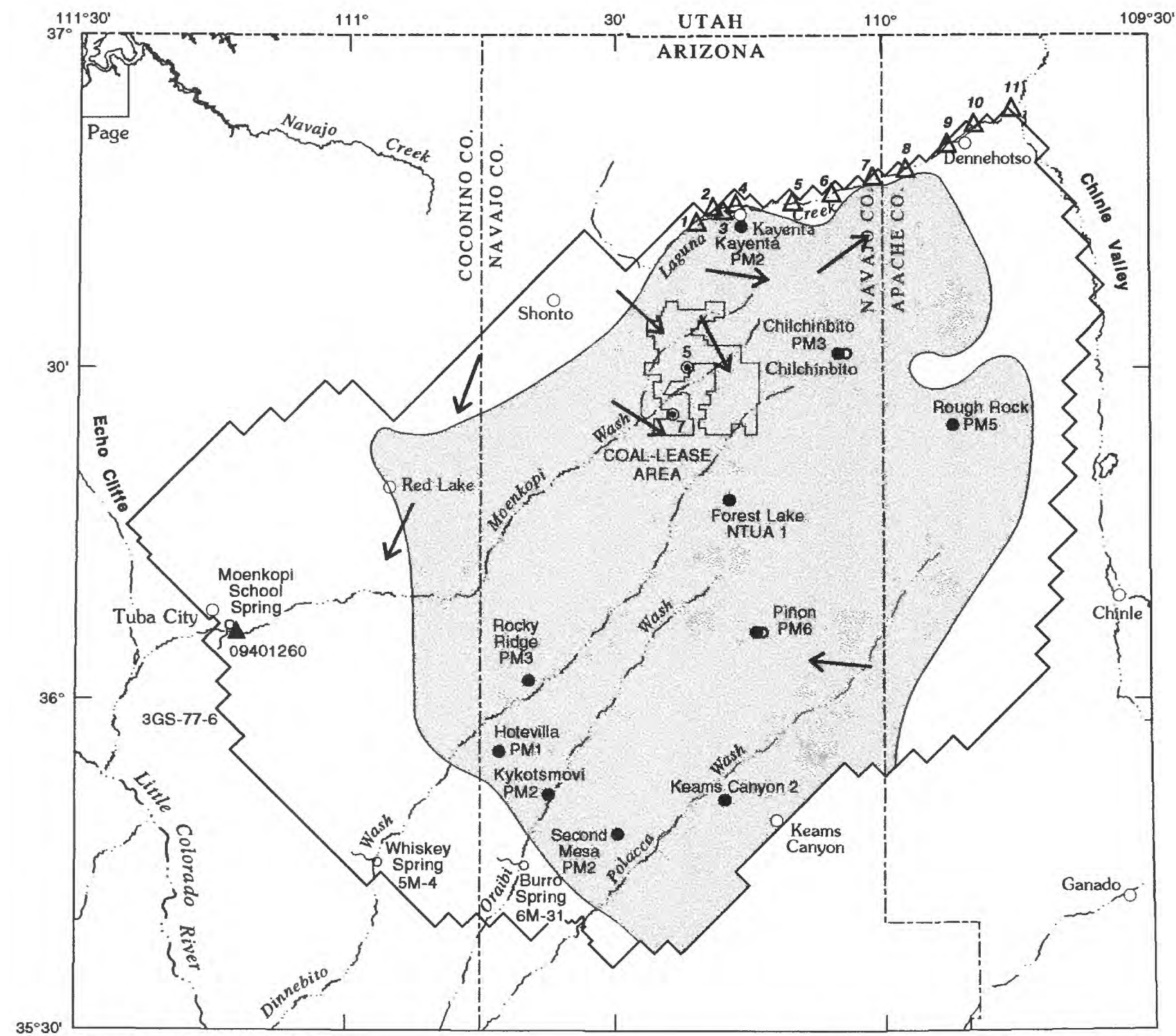

Base from U.S. Geological Survey digital data, 1:100,000, 1980

Lambert Conformal Conic projection

Standard parallels $29^{\circ} 30^{\circ}$ and $45^{\circ} 30^{\prime}$, central meridian $-96^{\circ} 00^{\circ}$

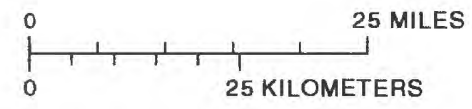

EXPLANATION

BOUNDARY BETWEEN CONFINED AND UNCONFINED CONDITIONS APPROXIMATE-From Eychaner (1983)

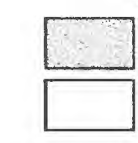

CONFINED

UNCONFINED

BOUNDARY OF MATHEMATICAL MODEL_From Eychaner (1983)

$\leftarrow$ GENERALIZED DIRECTION OF GROUND-WATER FLOW-From Brown and Eychaner (1988)
Modified from Brown and Eychaner (1988)

5 MILES 
Table 4. Discharge data, Moenkopi Wash at Moenkopi, calendar year 1994

[Dashes indicate no data]

DISCHARGE, IN CUBIC FEET PER SECOND, CALENDAR YEAR 1994

DAILY MEAN VALUES

\begin{tabular}{|c|c|c|c|c|c|c|c|c|c|c|c|c|}
\hline Day & Jan. & Feb. & Mar. & Apr. & May & June & July & Aug & Sept. & Oct.' & Nov. ${ }^{\prime}$ & Dec. ${ }^{1}$ \\
\hline 1 & 4.2 & 4.5 & 3.2 & 2.5 & 1.8 & 0.00 & 0.00 & 0.00 & 0.00 & 0.00 & 2.8 & 2.4 \\
\hline 2 & 3.9 & 4.3 & 3.2 & 2.1 & 1.8 & .00 & .00 & .00 & .00 & .09 & 2.7 & 2.4 \\
\hline 3 & 3.9 & 4.1 & 3.3 & 2.3 & 1.9 & .00 & .00 & .00 & .00 & .23 & 2.5 & 2.8 \\
\hline 4 & 4.0 & 4.2 & 3.4 & 2.5 & 1.8 & .00 & .00 & .00 & .00 & .34 & 2.6 & 3.3 \\
\hline 5 & 4.7 & 3.4 & 3.3 & 2.1 & 1.7 & .00 & .00 & .00 & .00 & .21 & 3.0 & 3.2 \\
\hline 6 & 4.5 & 3.5 & 3.3 & 1.9 & 1.5 & .00 & .00 & .00 & .00 & .49 & 3.5 & 4.3 \\
\hline 7 & 3.4 & 3.0 & 2.8 & 1.8 & 1.4 & .00 & .00 & .00 & .00 & 1.0 & 3.5 & 5.4 \\
\hline 8 & 3.7 & 3.5 & 3.7 & 1.9 & 1.2 & .00 & .00 & .00 & .00 & 1.3 & 3.5 & 2.7 \\
\hline 9 & 5.1 & 3.8 & 3.4 & 2.4 & 1.3 & .00 & .00 & .00 & .00 & 1.3 & 2.9 & 1.9 \\
\hline 10 & 4.6 & 3.3 & 3.1 & 2.8 & 1.5 & .00 & .00 & .00 & .00 & 1.3 & 3.1 & 3.2 \\
\hline 11 & 4.4 & 3.1 & 2.7 & 2.4 & 1.7 & .00 & .00 & .00 & .00 & 1.3 & 2.8 & 2.2 \\
\hline 12 & 4.3 & 3.3 & 3.0 & 2.0 & 4.1 & .00 & .00 & .00 & .00 & 1.3 & 3.3 & 2.5 \\
\hline 13 & 4.2 & 3.0 & 3.0 & 2.0 & 2.1 & .00 & .00 & .00 & .00 & 1.2 & 3.8 & 3.2 \\
\hline 14 & 3.9 & 23.0 & 2.9 & 2.0 & 1.8 & .00 & .00 & .00 & .00 & 1.2 & 2.8 & 3.1 \\
\hline 15 & 3.8 & 23.5 & 2.9 & 2.0 & 1.7 & .00 & .00 & .00 & .00 & 1.4 & 2.7 & 2.9 \\
\hline 16 & 4.4 & 3.6 & 2.9 & 2.0 & 1.3 & .00 & .00 & .00 & .00 & 1.9 & 2.3 & 4.0 \\
\hline 17 & 4.2 & 3.3 & 3.0 & 1.8 & .97 & .00 & .00 & .00 & .00 & 1.9 & 2.3 & 2.8 \\
\hline 18 & 4.2 & 3.3 & 2.5 & 2.0 & .81 & .00 & .00 & 40 & .00 & 1.3 & 2.2 & 3.0 \\
\hline 19 & 3.8 & 3.1 & 2.5 & 2.0 & .76 & .00 & .00 & 2.1 & .00 & 1.3 & 2.2 & 3.1 \\
\hline 20 & 4.4 & 3.3 & 3.7 & 1.9 & .81 & .00 & .00 & 1.4 & .00 & 1.5 & 2.1 & 3.0 \\
\hline 21 & 4.6 & 3.0 & 3.7 & 1.9 & 1.0 & .00 & .00 & 21 & .00 & 1.6 & 2.1 & 3.0 \\
\hline 22 & 4.5 & 2.9 & 2.8 & 1.8 & 1.1 & .00 & .00 & 3.1 & .00 & 1.6 & 2.2 & 3.6 \\
\hline 23 & 4.3 & 3.0 & 2.6 & 1.7 & 1.1 & .00 & .00 & .36 & .00 & 1.6 & 2.1 & 4.2 \\
\hline 24 & 4.5 & 3.1 & 2.3 & 1.5 & .91 & .00 & .00 & .00 & .00 & 1.5 & 2.3 & 3.8 \\
\hline 25 & 4.7 & 3.3 & 2.1 & 1.6 & 1.1 & .00 & .00 & .00 & .00 & 1.7 & 2.5 & 3.5 \\
\hline 26 & 4.0 & 3.2 & 2.9 & 2.5 & 1.6 & .00 & .00 & .00 & .00 & 1.9 & 2.7 & 3.1 \\
\hline 27 & 4.3 & 3.2 & 4.6 & 3.2 & 1.6 & .00 & .00 & .00 & .00 & 1.8 & 2.4 & 3.2 \\
\hline 28 & 3.9 & 3.8 & 2.5 & 2.2 & 1.3 & .00 & .00 & .00 & .00 & 1.9 & 2.2 & 3.3 \\
\hline 29 & 4.0 & --. & 2.3 & 2.1 & 1.1 & .00 & .00 & .24 & .00 & 2.1 & 1.9 & 3.1 \\
\hline 30 & 4.0 & --- & 2.2 & 1.8 & .84 & .00 & .00 & .02 & .00 & 2.2 & 2.1 & 2.7 \\
\hline 31 & ${ }^{2} 4.0$ & -.. & 2.2 & $\ldots$ & .49 & -.. & .00 & .00 & -- & 2.7 & --- & 3.2 \\
\hline
\end{tabular}

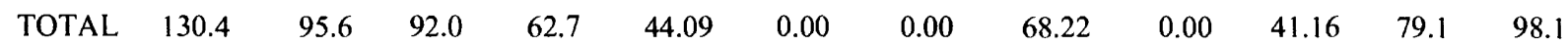

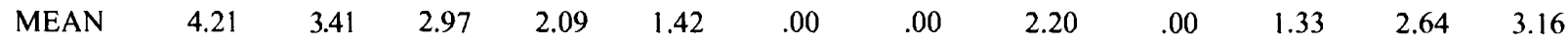

$\begin{array}{lllllllllllll}\text { MAX } & 5.1 & 4.5 & 4.6 & 3.2 & 4.1 & .00 & .00 & 40 & .00 & 2.7 & 3.8 & 5.4\end{array}$

$\begin{array}{lllllllllllll}\text { MIN } & 3.4 & 2.9 & 2.1 & 1.5 & .49 & .00 & .00 & .00 & .00 & .00 & 1.9 & 1.9\end{array}$

$\begin{array}{llllllllllll}\text { AC-FT } & 259 & 190 & 182 & 124 & 87 & .00 & .00 & 135 & .00 & 82 & 157\end{array}$

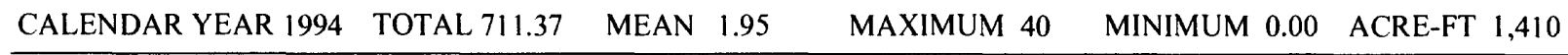

'Month in which data are provisional, subject to revision.

2 Estimated. 
Table 5. Discharge data from seepage investigation along Laguna Creek, 1994

[LSI, Laguna seepage investigation]

\begin{tabular}{|c|c|c|}
\hline $\begin{array}{l}\text { Base-flow } \\
\text { measure- } \\
\text { ment site } \\
\text { number }^{1}\end{array}$ & $\begin{array}{l}\text { Dis- } \\
\text { charge } \\
\text { (cubic } \\
\text { feet per } \\
\text { second) }\end{array}$ & Remarks $^{2}$ \\
\hline LSI-1 & 5.65 & Laguna Creek near Tsegi, Arizona, 10 feet below Tsegi gage (09379120) \\
\hline LSI-2 & 2.00 & Parrish Creek at bridge above confluence with Laguna Creek \\
\hline LSI-3 & .71 & Laguna Creek below diversion dam, 3 miles west of Kayenta, Arizona \\
\hline LSI-4 & 4.51 & Laguna Creek, 250 feet above bridge on Highway 464 at Kayenta, Arizona \\
\hline LSI-5 & 2.16 & Laguna Creek near Lion Rock, 3.5 miles northeast of Kayenta, Arizona \\
\hline LSI-6 & 2.08 & $\begin{array}{l}\text { Laguna Creek near Church Rock, } 7 \text { miles northeast of Kayenta, Arizona, at miscellaneous } \\
\text { measurement site }(09379160)\end{array}$ \\
\hline LSI-7 & 3.25 & Laguna Creek near Baby Rocks, 500 feet below falls, 14 miles northeast of Kayenta, Arizona \\
\hline LSI-8 & 5.88 & Laguna Creek near Red Point, 4 miles west of Dennehotso, Arizona \\
\hline LSI-9 & 3.32 & Laguna Creek above Dennehotso, 200 feet above diversion spillway gates \\
\hline LSI-10 & 1.12 & Laguna Creek below Dennehotso, 50 feet below bridge on Highway 164 \\
\hline LSI-11 & 1.47 & Laguna Creek, 300 feet above confluence with Chinle Wash \\
\hline
\end{tabular}

${ }^{1}$ Measurement-site numbers correlate to locations plotted on figure 6.

${ }^{2}$ All measurements were made on November 16, 1994.

Table 6. Discharge measurements of selected springs, 1952-94

\begin{tabular}{|c|c|c|c|c|}
\hline Spring name & $\begin{array}{l}\text { Bureau of } \\
\text { Indian Affairs } \\
\text { site number }\end{array}$ & Rock formations & $\begin{array}{c}\text { Date of } \\
\text { Measurement }\end{array}$ & $\begin{array}{l}\text { Discharge, in } \\
\text { gallons per } \\
\text { minute }\end{array}$ \\
\hline \multirow[t]{4}{*}{ Burro Spring } & $6 \mathrm{M}-31$ & Navajo Sandstone & $12-15-89$ & 0.4 \\
\hline & & & $12-13-90$ & .4 \\
\hline & & & $03-18-93$ & .3 \\
\hline & & & $12-08-94$ & .25 \\
\hline \multirow{6}{*}{$\begin{array}{l}\text { Moenkopi } \\
\text { School Spring }\end{array}$} & $3 G S-77-6$ & Navajo Sandstone tongue in the Kayenta Formation & $05-16-52$ & 40 \\
\hline & & & $04-22-87$ & 16 \\
\hline & & & $11-29-88$ & 12.5 \\
\hline & & & $02-21-91$ & ${ }^{1} 13.5$ \\
\hline & & & $04-07-93$ & ${ }^{1} 14.6$ \\
\hline & & & $12-07-94$ & ${ }^{1} 12.9$ \\
\hline \multirow[t]{4}{*}{ Whisky Spring } & $5 \mathrm{M}-4$ & Navajo Sandstone & $12-14-89$ & .1 \\
\hline & & & $12-14-90$ & .2 \\
\hline & & & $04-15-93$ & .1 \\
\hline & & & $12-07-94$ & 2.1 \\
\hline
\end{tabular}

\footnotetext{
'Discharge measured at water-chemistry sampling site only and does not represent the total discharge in the Moenkopi School Spring system. ${ }^{2}$ Estimated.
} 
1983). Any increase in the leakage rate as a result of pumping from the $\mathrm{N}$ aquifer probably would become evident as an increase in concentrations of dissolved solids, chloride, and sulfate in the most heavily pumped wells.

In general, water in the $\mathrm{N}$ aquifer is a calcium bicarbonate type in the upgradient or recharge part of the study area north and northwest of Black Mesa and a sodium bicarbonate type elsewhere throughout Black Mesa and surrounding areas (Kister and Hatchett, 1963). As water moves from the recharge area under Black Mesa toward discharge areas to the southwest and northeast (fig. 7), ion exchange along the flow path generally converts calcium type water to sodium type water. Locally, however, some wells penetrating the $\mathrm{N}$ aquifer may contain large concentrations of sulfate, chloride, and other ions introduced from waters of the $\mathrm{D}$ aquifer. Because wells tapping the $\mathrm{N}$ aquifer must pass through the $\mathrm{D}$ aquifer in the confined area, there is a potential for such wells to pull a mixture of water from both aquifers in places where well seals are either broken or inadequate, or if leakage is induced because of drawdown in the $\mathrm{N}$ aquifer. As of 1994, however, chemical data do not substantiate leakage through confining beds because of drawdown in the $\mathrm{N}$ aquifer.

All wells sampled in 1994 are completed in the confined area of the $\mathrm{N}$ aquifer (tables 7 and 8 and figs. 7 and 8). Ten of the 12 wells sampled, generally in upgradient areas of Black Mesa between the mine, Piñon, and Kykotsmovi, contained a sodium bicarbonate type water. Historically, water from well PM3 at Chilchinbito has been a sodium sulfate type water, and water from Kayenta PM2 has been a calcium bicarbonate type (Littin, 1993).

Dissolved-solids concentrations in water from wells in the $\mathrm{N}$ aquifer ranged from $130 \mathrm{mg} / \mathrm{L}$ at Peabody well No. 7 to $992 \mathrm{mg} / \mathrm{L}$ at the Chilchinbito well PM3 (fig. 8, tables 7 and 8). Long-term comparison of dissolved-solids concentrations in water taken from Keams Canyon 2, Piñon PM6, and Kayenta PM2 wells ${ }^{3}$ show no significant change from 1983 to 1994 (fig. 9, table 8). Since 1991, a gradual increase in concentrations of dissolved solids, sulfate, and chloride in water from the Forest Lake well NTUA 1 indicates that, locally, water from the $\mathrm{D}$ aquifer may be mixing with water from the $\mathrm{N}$ aquifer. ${ }^{4}$

\section{Surface Water}

Ten base-flow samples from Laguna Creek and one base-flow sample from Parrish Creek were analyzed in conjunction with the seepage investigation conducted in November 1994 (figs. 7 and 8, table 9). The water generally was a calcium bicarbonate water typical of the $\mathrm{N}$ aquifer in the unconfined area north of Black Mesa. Analyses of water downstream from Kayenta, however, showed an increase in dissolved solids that resulted in the water changing from a calcium bicarbonate to a sodium bicarbonate type. Dissolved solids increased from $180 \mathrm{mg} / \mathrm{L}$ at LSI- 1 near Tsegi to $335 \mathrm{mg} / \mathrm{L}$ at LSI-11 above the confluence with Chinle Wash. Water sampled at LSI-5 had the highest concentration of dissolved solids $(400 \mathrm{mg} / \mathrm{L})$. This increase in dissolved solids, specifically sodium, chloride, and sulfate ions (table 9), is believed to have been caused by sewage effluent discharging into Laguna Creek at Kayenta and Dennehotso. These data and the chemical analyses of ground water from the confined and unconfined areas of the $\mathrm{N}$ aquifer do not indicate that ground water from the confined area under Black Mesa discharges into Laguna Creek.

Three springs were selected for waterchemistry analyses as part of the monitoring program during 1994 (fig. 8, tables 10 and 11). The springs, all of which discharge from the Navajo Sandstone, are Burro Spring near Kykotsmovi, Moenkopi School Spring at Moenkopi, and Whisky Spring near Howell Mesa.

Historically, the chemistry of water from these springs has not changed significantly although there has been some increase in chloride and sulfate ions (table 11). Water from Burro Spring has been a sodium bicarbonate type; water from Moenkopi School Spring has been a calcium bicarbonate type water; and water from Whisky Spring has been a calcium sulfate type. Dissolved-solids concentrations in water from the three springs ranged from

\footnotetext{
${ }^{3}$ Well selection was based on sample frequency, length of record, consistency in sampling conditions, and representative spatiality.

${ }^{4}$ Water from Forest Lake NTUA 1 was sampled in August 1995. Specific conductance fluctuated between 410 and 492 $\mu \mathrm{S} / \mathrm{cm}$ during the 4 hours preceding sample collection and measured $470 \mu \mathrm{S} / \mathrm{cm}$ at time of sampling.
} 

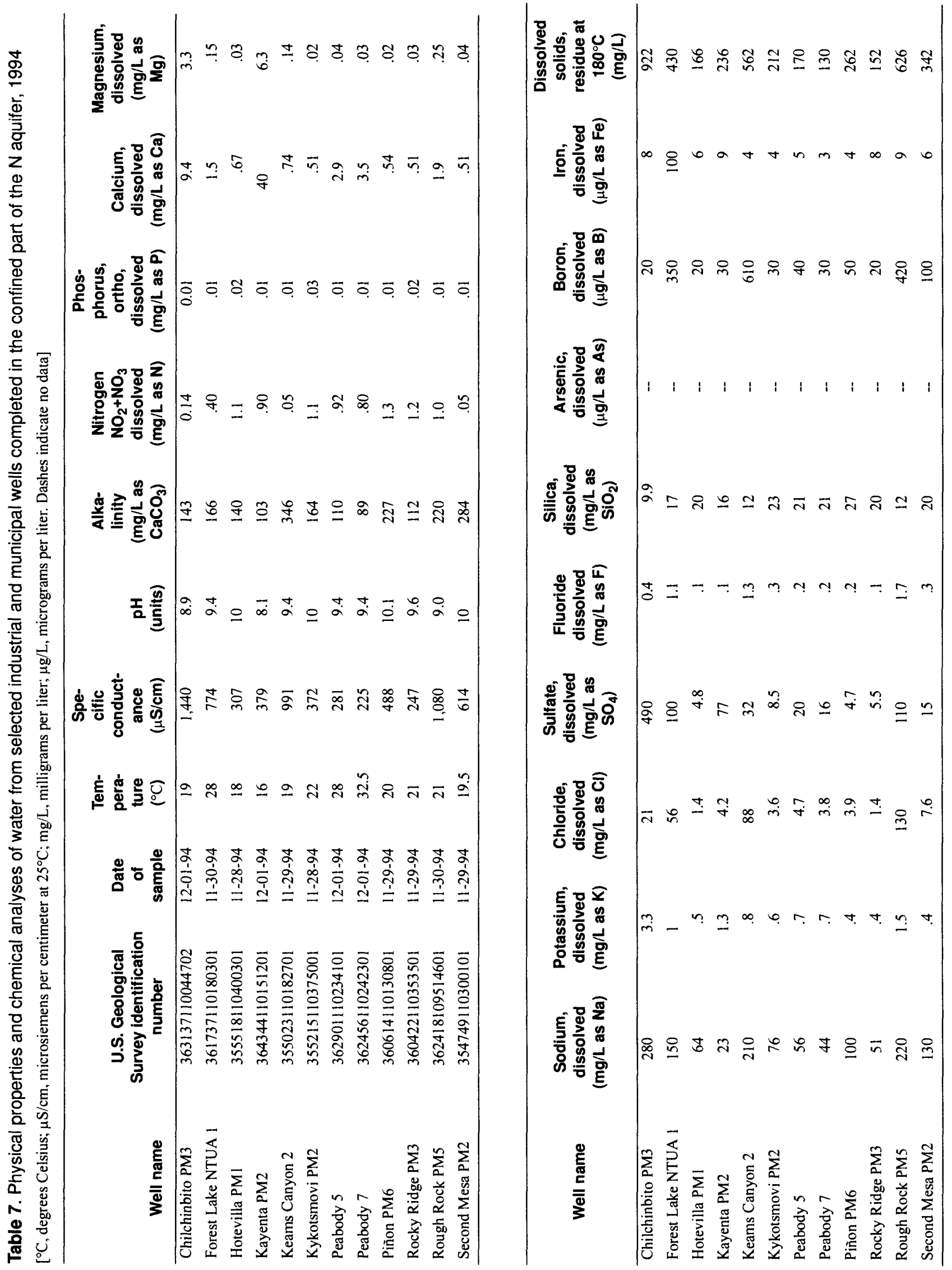


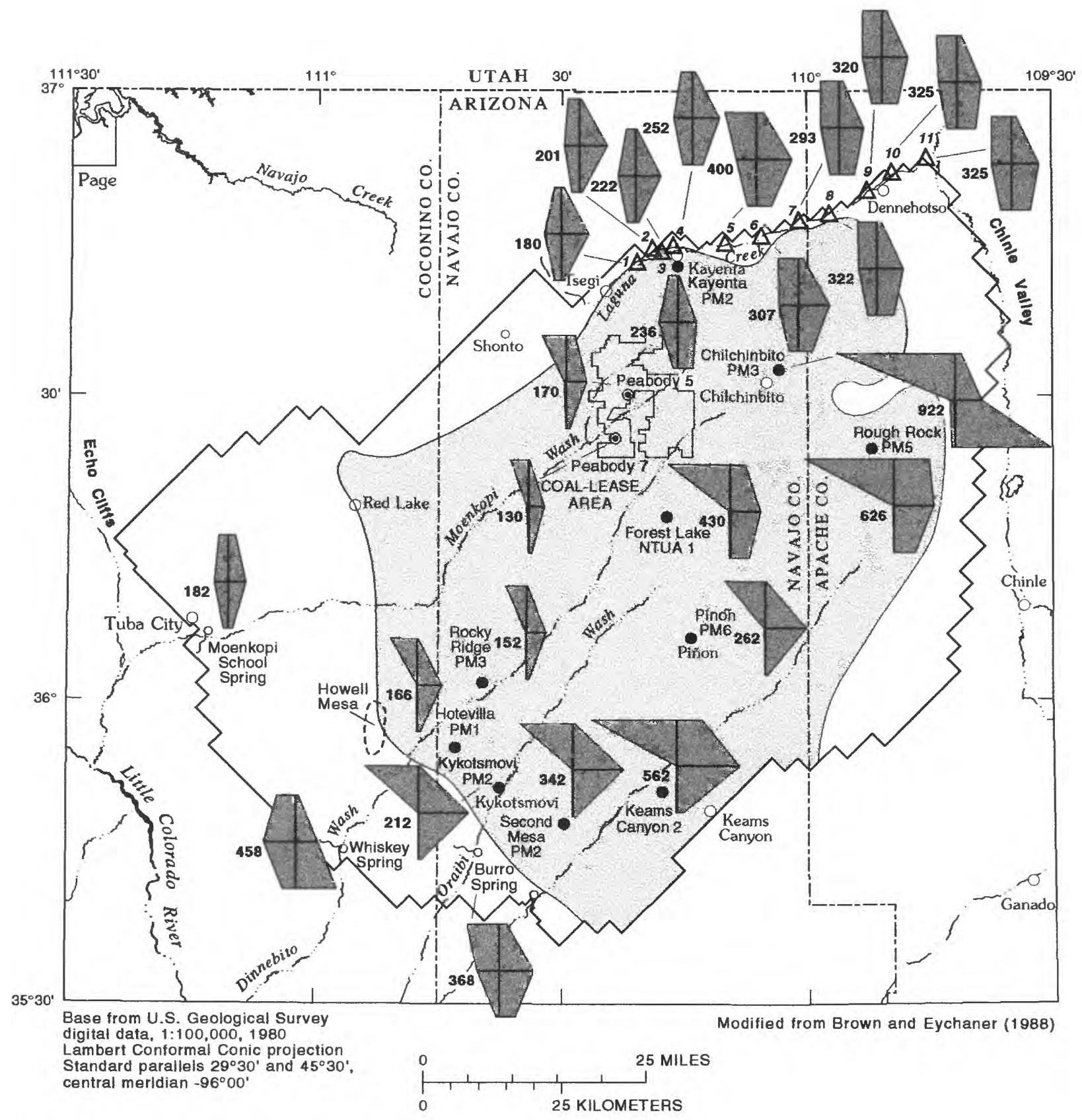

Figure 8. Water chemistry and distribution of dissolved solids in the $\mathrm{N}$ aquifer and Laguna Creek, 1994.

$182 \mathrm{mg} / \mathrm{L}$ at the Moenkopi School Spring to 458 $\mathrm{mg} / \mathrm{L}$ at Whisky Spring in 1994.

\section{SUMMARY}

The $\mathrm{N}$ aquifer is a major source of water for industrial and municipal uses in the Black Mesa area, and water occurs under confined and unconfined conditions. In 1994, combined groundwater withdrawals increased from 1993 by 8 percent to about 7,000 acre-ft. Pumpage from the confined part of the aquifer increased by about 9 percent to 5,400 acre-ft, and pumpage from the unconfined part of the aquifer increased by about 2 percent to 1,600 acre- $\mathrm{ft}$.

The median change in water levels in the confined area for 1994 was a decline of about $2.3 \mathrm{ft}$ as opposed to a decline of $3.3 \mathrm{ft}$ for 1993. In the unconfined area, the median change in water levels was a rise of $0.1 \mathrm{ft}$ as opposed to a decline of $0.4 \mathrm{ft}$ for 1993. 


\section{EXPLANATION}

BOUNDARY BETWEEN CONFINED AND UNCONFINED CONDITIONS APPROXIMATE-From Eychaner (1983)

CONFINED

UNCONFINED

BOUNDARY OF MATHEMATICAL MODEL-From Eychaner (1983)
Pinon MUNICIPAL WELL FROM WHICH WATER-CHEMISTRY SAMPLE WAS COLLECTED-PIก̃O PMG is well name

- INDUSTRIAL WEUL FROM WHICH WATER-CHEMISTAY SAMPLE WAS COLLECTED

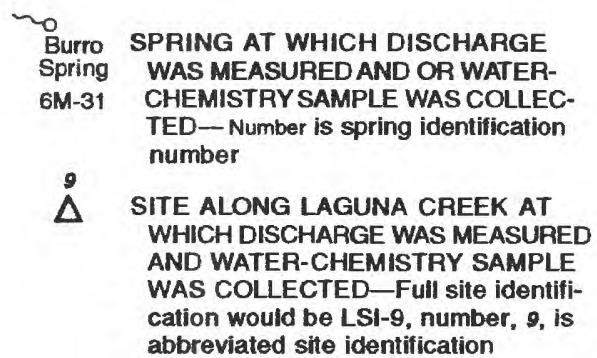

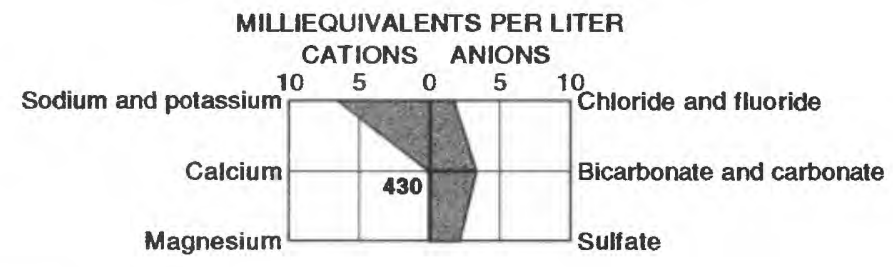

WATER-CHEMISTRY DIAGRAM - Shows major chemical constituents in milliequivalents per liter. The diagrams are in a variety of shapes and sizes, and provide a means of comparing, correlating, and characterizing types of water. Number, 430, is dissolved-solids concentration, in milligrams per liter

Figure 8. Continued.

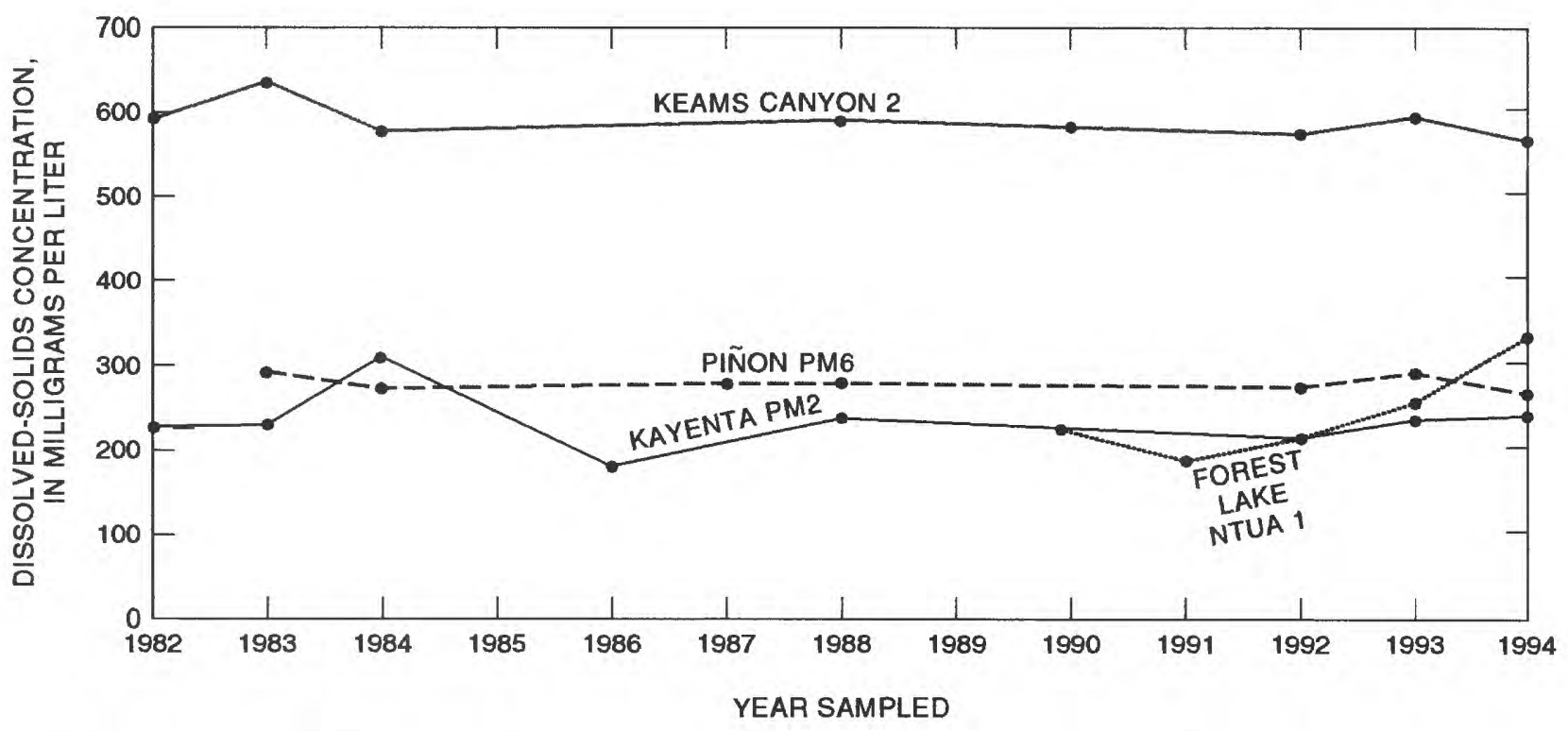

Figure 9. Dissolved-solids concentrations in water from wells Keams Canyon 2, Piñon PM6, Forest Lake NTUA 1, and Kayenta PM2, 1982-94.

Outflow from the $\mathrm{N}$ aquifer is mainly surface flow along Moenkopi Wash and Laguna Creek and discharge from springs near the boundaries of the aquifer. Measured low flow along Moenkopi Wash was about $2.9 \mathrm{ft}^{3 /} / \mathrm{s}$ in 1994 . Seepage measurements were made along a 40-mile reach of Laguna Creek in November 1994. Discharge was $5.6 \mathrm{ft}^{3} / \mathrm{s}$ near Tsegi and $1.5 \mathrm{ft}^{3} / \mathrm{s}$ above the confluence with Chinle
Wash. Maximum discharge was $5.9 \mathrm{ft}^{3} / \mathrm{s}$ about $4 \mathrm{mi}$ upstream from Dennehotso. Discharge at Burro and Whisky Springs was about the same as in 1993. Discharge from Moenkopi School Spring decreased from $14.6 \mathrm{gal} / \mathrm{min}$ in 1993 to $12.9 \mathrm{gal} / \mathrm{min}$ in 1994 .

Calcium bicarbonate water and sodium bicarbonate water are the primary types of water that occur in the $\mathrm{N}$ aquifer. Calcium bicarbonate 
Table 8. Specific conductance and concentrations of selected chemical constituents in water from industrial and municipal wells completed in the confined part of the $\mathrm{N}$ aquifer, 1980-94

$\left[\mu \mathrm{S} / \mathrm{cm}\right.$, microsiemens per centimeter at $25^{\circ} \mathrm{C} ; \mathrm{mg} / \mathrm{L}$, milligrams per liter; ${ }^{\circ} \mathrm{C}$, degrees Celsius. Dashes indicate no data]

\begin{tabular}{|c|c|c|c|c|c|c|c|c|c|}
\hline Year & $\begin{array}{c}\text { Specific } \\
\text { conduct- } \\
\text { ance } \\
(\mu \mathrm{S} / \mathrm{cm})\end{array}$ & $\begin{array}{l}\text { Dissolved } \\
\text { sollds } \\
\text { concen- } \\
\text { trations, } \\
\text { residue at } \\
180^{\circ} \mathrm{C} \\
(\mathrm{mg} / \mathrm{L})\end{array}$ & $\begin{array}{l}\text { Chlo- } \\
\text { ride, dis- } \\
\text { solved } \\
\text { (mg/L as } \\
\mathrm{Cl})\end{array}$ & $\begin{array}{l}\text { Sulfate, } \\
\text { dis- } \\
\text { solved } \\
\left(\mathrm{mg}^{\prime} \mathrm{L} \text { as }\right. \\
\left.\mathrm{SO}_{4}\right)\end{array}$ & Year & $\begin{array}{c}\text { Specific } \\
\text { conduct- } \\
\text { ance } \\
(\mu \mathrm{S} / \mathrm{cm})\end{array}$ & $\begin{array}{l}\text { Dissolved } \\
\text { solids } \\
\text { concen- } \\
\text { trations, } \\
\text { residue at } \\
180^{\circ} \mathrm{C} \\
(\mathrm{mg} / \mathrm{L})\end{array}$ & $\begin{array}{l}\text { Chlo- } \\
\text { ride, dis- } \\
\text { solved } \\
\text { (mg/L as } \\
\mathrm{CI})\end{array}$ & $\begin{array}{c}\text { Sulfate, } \\
\text { dis- } \\
\text { solved } \\
\left(\mathrm{mg}^{\prime} \mathrm{L} \text { as }\right. \\
\left.\mathrm{SO}_{4}\right)\end{array}$ \\
\hline \multicolumn{5}{|c|}{ Chilchinbito PM3 } & \multicolumn{5}{|c|}{ Peabody 5} \\
\hline 1986 & 390 & 231 & 2.5 & 11 & 1980 & 210 & 134 & 2.9 & 9.5 \\
\hline 1988 & 414 & 256 & 2.7 & 31 & 1986 & 398 & - & 8 & 28 \\
\hline 1991 & 1,500 & 952 & 11 & 620 & 1987 & 270 & 168 & 4.6 & 21 \\
\hline 1992 & 1,287 & 812 & 33 & 430 & 1988 & 270 & 183 & 5.1 & 22 \\
\hline 1993 & 1,030 & 598 & 7.5 & 320 & 1988 & 263 & 174 & 4.1 & 26 \\
\hline 1994 & 1,440 & 992 & 21 & 490 & 1990 & 262 & 152 & 4.1 & 18 \\
\hline \multicolumn{5}{|c|}{ Forest Lake NTUA I } & 1991 & 260 & 178 & 3 & 18 \\
\hline 1982 & 470 & -- & 11 & 67 & 1993 & 257 & 112 & 2.3 & 4.8 \\
\hline 1990 & 375 & 226 & 8.2 & 38 & 1994 & 281 & 170 & 4.7 & 20 \\
\hline 1991 & 350 & 183 & 10 & 24 & \multicolumn{5}{|c|}{ Peabody 7} \\
\hline 1993 & 693 & 352 & 35 & 88 & 1980 & 210 & 136 & 3.7 & 11 \\
\hline 1994 & 744 & 430 & 56 & 100 & 1986 & 217 & - & 3.6 & 12 \\
\hline \multicolumn{5}{|c|}{ Hotevilla PMI } & 1988 & 240 & 151 & 4.4 & 18 \\
\hline 1990 & 290 & 192 & 1.6 & 5 & 1993 & 228 & 128 & 3.8 & 16 \\
\hline 1991 & 304 & 208 & .7 & 5.4 & 1994 & 225 & 130 & 3.8 & 16 \\
\hline 1993 & 305 & 180 & 1.2 & 5.5 & \multicolumn{5}{|c|}{ Piñon PM6 } \\
\hline 1994 & 307 & 166 & 1.4 & 4.8 & 1982 & 485 & - & 3.7 & 5 \\
\hline \multicolumn{5}{|c|}{ Kayenta PM2 } & 1983 & 505 & 293 & 3.6 & 3.5 \\
\hline 1982 & 360 & 228 & 4.5 & 58 & 1984 & 495 & 273 & 3.7 & 5.4 \\
\hline 1983 & 375 & 230 & -- & 60 & 1987 & 500 & 279 & 3.7 & 3.8 \\
\hline 1984 & 365 & 309 & 4.2 & 51 & 1988 & 455 & 278 & 3.5 & 5.2 \\
\hline 1986 & 300 & 181 & 8.2 & 30 & 1992 & 488 & 270 & 7 & 8.6 \\
\hline 1988 & 358 & 235 & 3.8 & 74 & 1993 & 488 & 287 & 3.6 & 4.5 \\
\hline 1992 & 383 & 210 & 5.6 & 78 & 1994 & 488 & 262 & 3.9 & 4.7 \\
\hline 1993 & 374 & 232 & 3.7 & 78 & \multicolumn{5}{|c|}{ Rocky Ridge PM3 } \\
\hline 1994 & 379 & 236 & 4.2 & 77 & 1982 & 255 & - & 1.4 & 6 \\
\hline \multicolumn{5}{|c|}{ Keams Canyon 2} & 1990 & 222 & 126 & 1.5 & 6 \\
\hline 1982 & 1,010 & 592 & 94 & 35 & 1993 & 254 & 146 & 1.3 & 5.5 \\
\hline 1983 & 1,120 & 636 & 120 & 42 & 1994 & 247 & 152 & 1.4 & 5.5 \\
\hline 1984 & 1,040 & 578 & 96 & 36 & \multicolumn{5}{|c|}{ Rough Rock PM5 } \\
\hline 1988 & 1,040 & 591 & 97 & 34 & 1983 & 1,090 & 628 & 130 & 110 \\
\hline 1990 & 1,030 & 600 & 94 & 34 & 1984 & 1,090 & 613 & 130 & 99 \\
\hline 1992 & 1,008 & 570 & 93 & 36 & 1986 & 1,010 & 633 & 140 & 120 \\
\hline 1993 & 1,040 & 590 & 92 & 36 & 1988 & 1,120 & 624 & 130 & 109 \\
\hline 1994 & 991 & 562 & 88 & 32 & 1991 & 1,060 & 574 & 130 & 110 \\
\hline \multicolumn{5}{|c|}{ Kykotsmovi PM2 } & 1993 & 1,040 & 614 & 130 & 110 \\
\hline 1988 & 368 & 212 & 3.2 & 8.6 & 1994 & 1,080 & 626 & 130 & 110 \\
\hline 1990 & 355 & 255 & 3.2 & 9 & \multicolumn{5}{|c|}{ Second Mesa PM2 } \\
\hline 1991 & 372 & 203 & 4.4 & 7.9 & 1990 & 590 & 364 & 6.5 & 16 \\
\hline 1993 & 363 & 212 & 3.3 & 8.4 & 1991 & 613 & 292 & 10 & 15 \\
\hline \multirow[t]{2}{*}{1994} & 372 & 212 & 3.6 & 8.5 & 1993 & 630 & 350 & 7.5 & 15 \\
\hline & & & & & 1994 & 614 & 342 & 7.6 & 15 \\
\hline
\end{tabular}




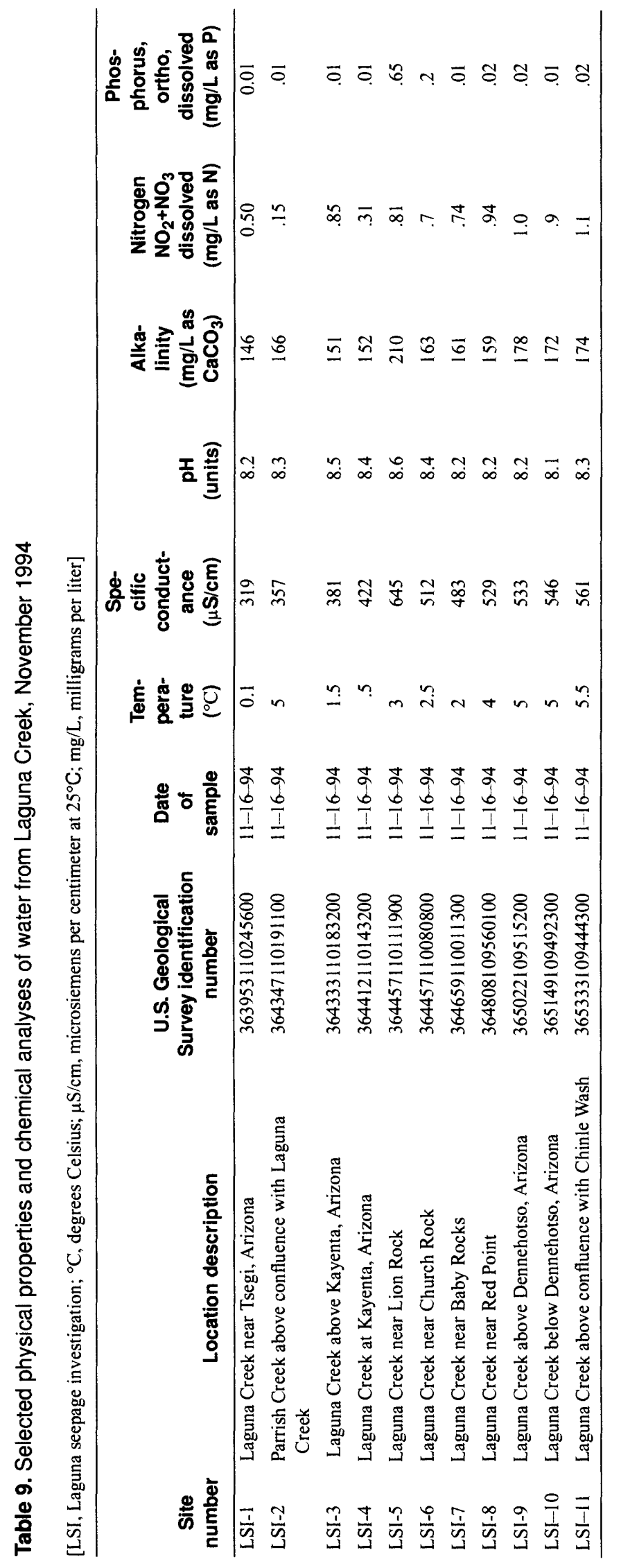

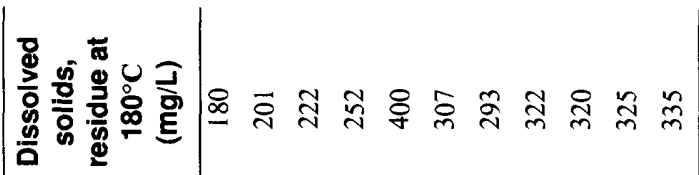
के

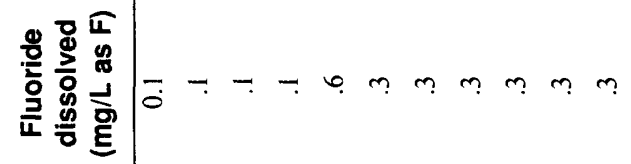

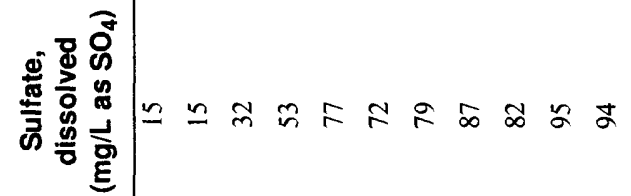

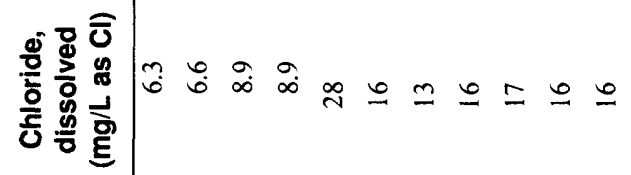

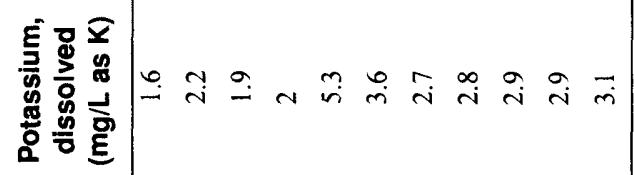

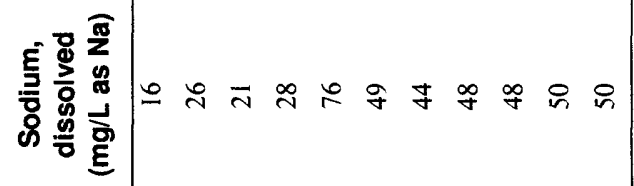

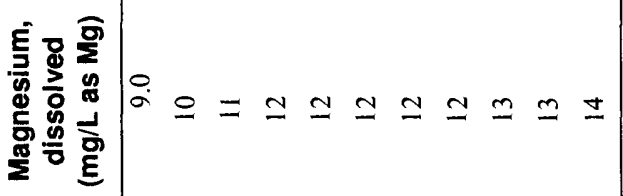

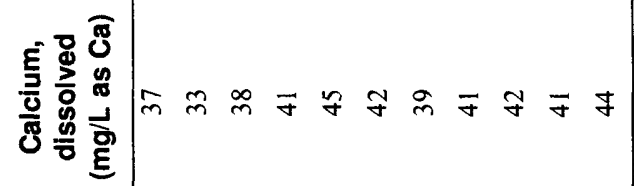

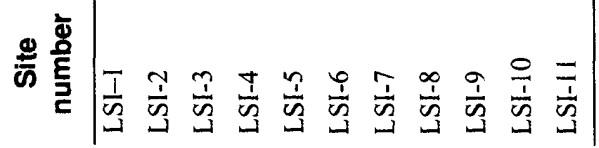


Table 10. Selected physical properties and chemical analyses of water from selected springs in the Black Mesa area, 1994

$\left[{ }^{\circ} \mathrm{C}\right.$, degree Celsius; $\mu \mathrm{S} / \mathrm{cm}$, microsiemens per centimeter at $25^{\circ} \mathrm{C} ; \mathrm{mg} / \mathrm{L}$, milligrams per liter; $\mu \mathrm{g} / \mathrm{L}$, micrograms per liter. Dashes indicate no data]

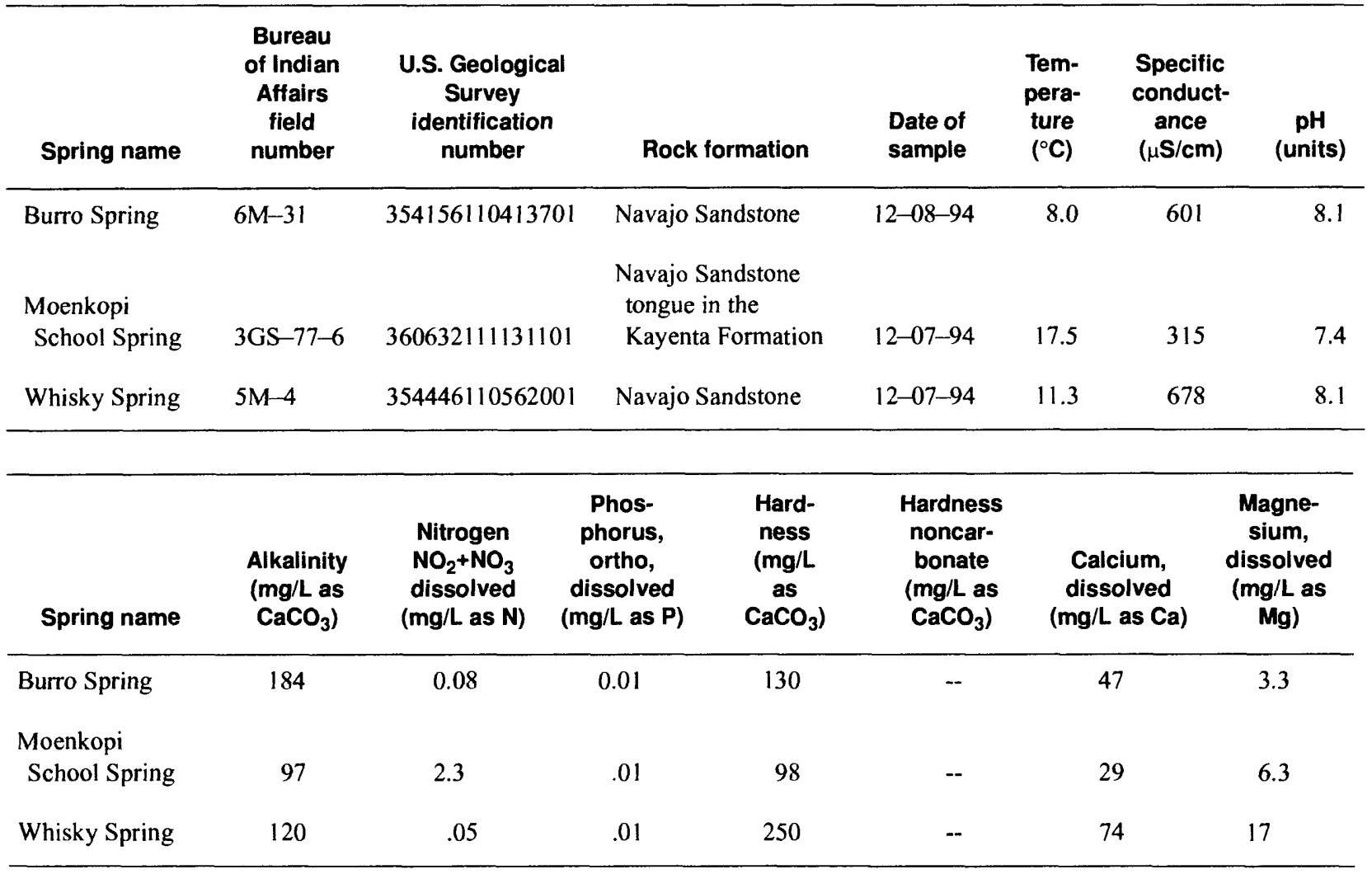

\begin{tabular}{|c|c|c|c|c|c|c|c|}
\hline Spring name & $\begin{array}{c}\text { Sodium, } \\
\text { dissolved } \\
(\mathrm{mg} / \mathrm{L} \text { as } \mathrm{Na})\end{array}$ & $\begin{array}{l}\text { Sodium } \\
\text { adsorption ratio }\end{array}$ & Percent sodium & $\begin{array}{r}\text { Sodium p } \\
\text { potassiu } \\
\text { dissolve } \\
\text { (mg/L as } \mathrm{N}\end{array}$ & $\begin{array}{l}\text { lus } \\
\text { m, } \\
a+k)\end{array}$ & $\begin{array}{l}\text { Potassium, } \\
\text { dissolved } \\
\text { (mg/L as K) }\end{array}$ & $\begin{array}{c}\text { Chloride, } \\
\text { dissolved } \\
\text { (mg/L as } \mathrm{Cl})\end{array}$ \\
\hline Burro Spring & 81 & 3 & 58 & \multicolumn{2}{|l|}{81.5} & 0.5 & 26 \\
\hline \multicolumn{8}{|l|}{ Moenkopi } \\
\hline School Spring & 24 & 1 & 35 & \multicolumn{2}{|l|}{25.3} & 1.3 & 17 \\
\hline Whisky Spring & 45 & 1 & 28 & \multicolumn{2}{|l|}{47.9} & 2.9 & 8.4 \\
\hline Spring name & $\begin{array}{c}\text { Sulfate, } \\
\text { dissolved } \\
\left(\mathrm{mg} / \mathrm{L} \text { as } \mathrm{SO}_{4}\right)\end{array}$ & $\begin{array}{c}\text { Fluoride } \\
\text { dissolved } \\
\text { (mg/L as F) }\end{array}$ & $\begin{array}{c}\text { Silica, } \\
\text { dissolved } \\
\left(\mathrm{mg} / \mathrm{L} \text { as } \mathrm{SiO}_{2}\right)\end{array}$ & $\begin{array}{c}\text { Arsenic, } \\
\text { dissolved } \\
(\mu \mathrm{g} / \mathrm{L} \text { as As })\end{array}$ & $\begin{array}{c}\text { Boron, } \\
\text { dissolved } \\
(\mu \mathrm{g} / \mathrm{L} \text { as B) }\end{array}$ & $\begin{array}{c}\text { Iron, } \\
\text { dissolved } \\
(\mu \mathrm{g} / \mathrm{L} \text { as } \\
\mathrm{Fe})\end{array}$ & $\begin{array}{l}\text { Dissolved } \\
\text { solids, } \\
\text { residue at } \\
180^{\circ} \mathrm{C} \\
(\mathrm{mg} / \mathrm{L})\end{array}$ \\
\hline Burro Spring & 80 & 0.4 & 13 & -- & 70 & 13 & 368 \\
\hline Moenkopi & & & & -- & & & \\
\hline School Spring & 23 & .1 & 14 & & 40 & 3 & 182 \\
\hline Whisky Spring & 210 & .3 & 16 & -- & 40 & 4 & 458 \\
\hline
\end{tabular}


Table 11. Specific conductance and concentrations of selected chemical constituents in water from springs that discharge from the $\mathrm{N}$ aquifer, 1952-94

$\left[\mu \mathrm{S} / \mathrm{cm}\right.$, microsiemens per centimeter at $25^{\circ} \mathrm{C} ; \mathrm{mg} / \mathrm{L}$, milligrams per liter; ${ }^{\circ} \mathrm{C}$, degrees Celsius. Dashes indicate no data]

\begin{tabular}{|c|c|c|c|c|c|}
\hline $\begin{array}{l}\text { Spring } \\
\text { name }\end{array}$ & Year & $\begin{array}{l}\text { Spe- } \\
\text { cific } \\
\text { con- } \\
\text { duct- } \\
\text { ance } \\
(\mu \mathrm{S} / \mathrm{cm})\end{array}$ & $\begin{array}{l}\text { Dissolved- } \\
\text { solids con- } \\
\text { centrations, } \\
\text { residue at } \\
180^{\circ} \mathrm{C} \\
(\mathrm{mg} / \mathrm{L})\end{array}$ & $\begin{array}{l}\text { Chlo- } \\
\text { ride, } \\
\text { dis- } \\
\text { solved } \\
\text { (mg/L } \\
\text { as } \mathrm{Cl} \text { ) }\end{array}$ & $\begin{array}{c}\text { Sulfate, } \\
\text { dis- } \\
\text { solved } \\
(\mathrm{mg} / \mathrm{L} \\
\left.\text { as } \mathrm{SO}_{4}\right)\end{array}$ \\
\hline Burro & 1989 & 485 & 308 & 22 & 59 \\
\hline \multirow[t]{3}{*}{ Spring } & I 990 & 546 & 347 & 23 & 65 \\
\hline & I 993 & 595 & 368 & 30 & 85 \\
\hline & 1994 & 601 & 368 & 26 & 80 \\
\hline Moenkopi & 1952 & 222 & --- & 6 & --- \\
\hline School & 1987 & 270 & 161 & 12 & 19 \\
\hline \multirow[t]{4}{*}{ Spring } & 1988 & 270 & 155 & 12 & 19 \\
\hline & 199| & 287 & 157 & 14 & 20 \\
\hline & 1993 & 313 & 204 & 17 & 27 \\
\hline & 1994 & 315 & 182 & 17 & 23 \\
\hline Whisky & 1954 & 639 & --- & 10 & 189 \\
\hline \multirow[t]{4}{*}{ Spring } & 1989 & 560 & 455 & 7.8 & 219 \\
\hline & 1990 & 676 & 451 & 10 & 240 \\
\hline & 1993 & 660 & 464 & 9.1 & 220 \\
\hline & 1994 & 678 & 458 & 8.4 & 210 \\
\hline
\end{tabular}

water occurs in the part of the study area north of Black Mesa. The sodium bicarbonate water generally occurs elsewhere throughout the area. All but two of the wells sampled in 1994 contained a sodium bicarbonate type water. Historically, water from Chilchinbito PM3 has been a sodium sulfate type, and water from Kayenta PM2 has been a calcium bicarbonate type. Dissolved-solids concentrations ranged from about 130 to $992 \mathrm{mg} / \mathrm{L}$ in 1994.

Ten base-flow samples from Laguna Creek and one base-flow sample from Parrish Creek were analyzed in conjunction with the seepage investigation of November 1994. These analyses of ground water from the confined and unconfined areas of the $\mathrm{N}$ aquifer do not indicate that ground water from the confined area under Black Mesa discharges into Laguna Creek.

The potential exists for downward movement of water from the $\mathrm{D}$ aquifer to the $\mathrm{N}$ aquifer. Recent gradual increases in concentrations of dissolved solids, sulfate, and chloride in water from Forest Lake NTUA 1 indicates some local mixing may be occurring with water from the $\mathrm{D}$ aquifer. Regionally, however, long-term water-chemistry data for wells and springs show no discernible change in water quality.

\section{REFERENCES CITED}

Arizona Department of Economic Security, 1991, Population statistics of the Navajo and Hopi Reservations, 1990 census: Phoenix, Arizona Department of Economic Security unpublished data. Boner, F.C., Davis, R.G., and Duet, N.R., 1992, Water-resources data for Arizona, water year 1991: U.S. Geological Survey Water-Data Report AZ-91-1, $411 \mathrm{p}$.

Boner, F.C., Garrett, W.B., and Konieczki, A.D., 1989, Water-resources data for Arizona, water year 1988: U.S. Geological Survey Water-Data Report AZ-88-1, $391 \mathrm{p}$.

Boner, F.C., Konieczki, A.D., and Davis, R.G., 1991, Water-resources data for Arizona, water year 1990: U.S. Geological Survey Water-Data Report AZ-90-1, $381 \mathrm{p}$.

Boner, F.C., Smith, C.F., Garrett, W.B., and Konieczki, A.D., 1990, Water-resources data for Arizona, water year 1989: U.S. Geological Survey Water-Data Report AZ-89-1, 383 p.

Brown, J.G., and Eychaner, J.H., 1988, Simulation of five ground-water withdrawal projections for the Black Mesa area, Navajo and Hopi Indian Reservations, Arizona: U.S. Geological Survey Water-Resources Investigations Report 88-4000, $51 \mathrm{p}$.

Cooley, M.E., Harshbarger, J.W., Akers, J.P., and Hardt, W.F., 1969, Regional hydrogeology of the Navajo and Hopi Indian Reservations, Arizona, New Mexico, and Utah: U.S. Geological Survey Professional Paper 521-A, $61 \mathrm{p}$.

Davis, G.E., Hardt, W.F., Thompson, L.K., and Cooley, M.E., 1963, Records of ground-water supplies, part 1, of Geohydrologic data in the Navajo and Hopi Indian Reservations, Arizona, New Mexico, and Utah: Arizona State Land Department Water-Resources Report 12-A, $159 \mathrm{p}$.

Dubiel, R.F., 1989, Sedimentology and revised nomenclature for the upper part of the upper Triassic Chinle Formation and the lower Jurassic Wingate Sandstone, northwestern New Mexico and northeastern Arizona, in Anderson, O.J., Lucas, S.G., Love, D.W., and Cather, S.M., eds., Southeastern Colorado Plateau: New Mexico Geological Society Fortieth Annual Field Conference, September 28-October 1, 1989, p. 213-223. 
Eychaner, J.H., 1983, Geohydrology and effects of water use in the Black Mesa area, Navajo and Hopi Indian Reservations, Arizona: U.S. Geological Survey Water-Supply Paper 2201, 26 p.

Garrett, J.M., and Gellenbeck, D.J., 1991, Basin characteristics and streamflow statistics in Arizona as of 1989: U.S. Geological Survey WaterResources Investigations Report 91-4041, 612 p.

Harshbarger, J.W., Lewis, D.D., Skibitzke, H.E., Heckler, W.L., and Kister, L.R., 1966, Arizona water: U.S. Geological Survey Water-Supply Paper $1648,85 \mathrm{p}$.

Hart, R.J., and Sottilare, J.P., 1988, Progress report on the ground-water, surface-water, and quality-of-water monitoring program, Black Mesa area, northeastern Arizona-1987-88: U.S. Geological Survey Open-File Report 88-467, 27 p.

1989, Progress report on the ground-water, surface-water, and quality-of-water monitoring program, Black Mesa area, northeastern Arizona-1988-89: U.S. Geological Survey Open-File Report 89-383, 33 p.

Hill, G.W., 1985, Progress report on Black Mesa monitoring program-1984: U.S. Geological Survey Open-File Report 85-483, 24 p.

Hill, G.W., and Sottilare, J.P., 1987, Progress report on the ground-water, surface-water, and quality-ofwater monitoring program, Black Mesa area, northeastern Arizona-1987: U.S. Geological Survey Open-File Report 87-458, 29 p.

Hill, G.W., and Whetten, M.I., 1986, Progress report on Black Mesa monitoring program-1985-86: U.S. Geological Survey Open-File Report 86-414, 23 p.

Kister, L.R., and Hatchett, J.L., 1963, Selected chemical analyses of the ground water, pt. 2 of Geohydrologic data in the Navajo and Hopi Indian Reservations, Arizona, New Mexico, and Utah: Arizona State Land Department Water-Resources Report 12-B, $58 \mathrm{p}$.

Littin, G.R., 1992, Results of ground-water, surface-water, and water-quality monitoring, Black Mesa area, northeastern Arizona-1990-91: U.S. Geological Survey Water-Resources Investigations Report 92-4045, $32 \mathrm{p}$.

1993, Results of ground-water, surface-water, and water-quality monitoring, Black Mesa area, northeastern Arizona-1991-92: U.S. Geological Survey Water-Resources Investigations Report 93-4111, $23 \mathrm{p}$.

Littin, G.R., and Monroe, S.A., 1995, Results of ground-water, surface-water, and water-quality monitoring, Black Mesa area, northeastern Arizona-1992-93: U.S. Geological Survey
Water-Resources Investigations Report 95-4156, $37 \mathrm{p}$.

Peterson, Fred, 1988, Stratigraphy and nomenclature of middle and upper Jurassic rocks, Western Colorado Plateau, Utah and Arizona, in Revisions to Stratigraphic Nomenclature of Jurassic and Cretaceous Rocks of the Colorado Plateau: U.S. Geological Survey Bulletin 1633-B, p. 13-56.

Smith, C.F., Anning, D.W., Duet, N.R., Fisk, G.G., McCormack, H.F., Pope, G.L., Rigas, P.D., and Wallace, B.L., 1995, Water-resources data for Arizona, water year 1994: U.S. Geological Survey Water-Data Report AZ-94-1, 320 p.

Smith, C.F., Boner, F.C., Davis, R.G., Duet, N.R., and Rigas, P.D., 1993, Water-resources data for Arizona, water year 1992: U.S. Geological Survey Water-Data Report AZ-92-1, 360 p.

Smith, C.F., Rigas, P.D., Ham, L.K., Duet, N.R., and Anning, D.W., 1994, Water-resources data for Arizona, water year 1993: U.S. Geological Survey Water-Data Report AZ-93-1, 360 p.

Sottilare, J.P., 1992, Results of ground-water, surface-water, and water-quality monitoring, Black Mesa area, northeastern Arizona-1989-90: U.S. Geological Survey Water-Resources Investigations Report 92-4008, 38 p.

U.S. Geological Survey, 1963-64, Surface-water records of Arizona: U.S. Geological Survey report (published annually).

1963-64, Ground-water records of Arizona: U.S. Geological Survey report (published annually).

1965-74, Water resources data for Arizona-Part 1, Surface-water records: U.S. Geological Survey Water-Resources Data Report (published annually).

1965-74, Water resources data for Arizona-Part 2, Ground-water records: U.S. Geological Survey Water-Data Report (published annually).

1975-81, Water-resources data for Arizona, water years 1963-81: U.S. Geological Survey Water-Resources Data Reports AZ-75-1 to AZ-81-1 (published annually).

1978, Progress report on Black Mesa monitoring program-1977: U.S. Geological Survey Open-File Report 78-459, 38 p.

White, N.D., and Garrett, W.B., 1984, Water-resources data for Arizona, water year 1982: U.S. Geological Survey Water-Data Report AZ-82-1, 440 p.

1986, Water-resources data for Arizona, water year 1983: U.S. Geological Survey Water-Data Report AZ-83-1, 387 p. 
1987, Water-resources data for Arizona, water year 1984: U.S. Geological Survey Water-Data Report AZ-84-1, $381 \mathrm{p}$.

1988, Water-resources data for Arizona, water year 1985: U.S. Geological Survey Water-Data Report AZ-85-1, 343 p.
Wilson, R.P., and Garrett, W.B., 1988, Water-resources data for Arizona, water year 1986: U.S. Geological Survey Water-Data Report AZ-86-1, 341 p.

1989, Water-resources data for Arizona, water year 1987: U.S. Geological Survey Water-Data Report AZ-87-1, 385 p. 